\title{
A Roadmap for Investment Promotion and Export Diversification: The Case of Jordan
}

Ricardo Hausmann, Patricio Goldstein, Ana Grisanti, Tim O'Brien, Jorge Tapia, and Miguel Angel Santos

CID Faculty Working Paper No. 374

December 2019

Revised March 2020

(C) Copyright 2020, 2019 Hausmann, Ricardo; Goldstein, Patricio; Grisanti, Ana; O'Brien, Tim; Tapia, Jorge; Santos, Miguel Angel; and the President and Fellows of Harvard College
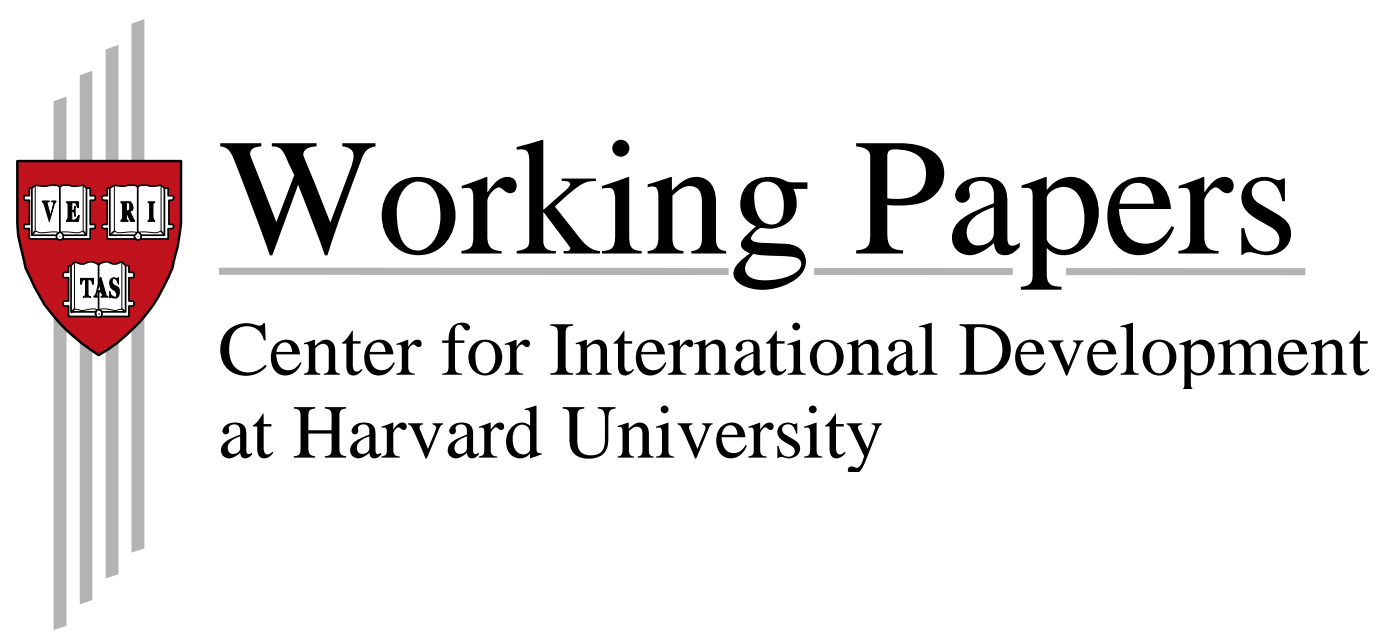


\section{A Roadmap for Investment Promotion and Export Diversification: The Case of Jordan}

Ricardo Hausmann, Patricio Goldstein, Ana Grisanti, Tim O’Brien, Jorge Tapia, and Miguel Angel Santos

Harvard CID Working Paper

December 2019

CCopyright 2019 Hausmann, Ricardo; Goldstein, Patricio; Grisanti, Ana; O’Brien, Tim; Tapia, Jorge; Santos, Miguel Angel; and the President and Fellows of Harvard College

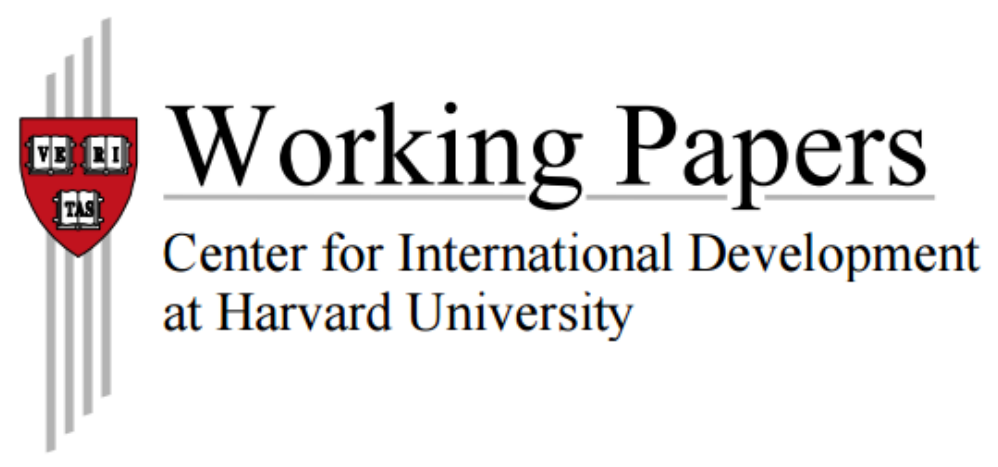




\section{Table of Contents}

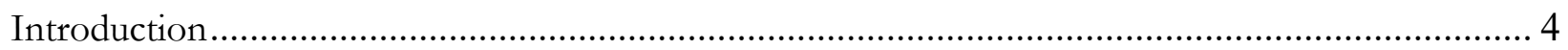

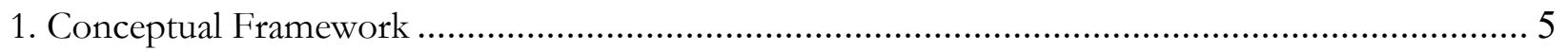

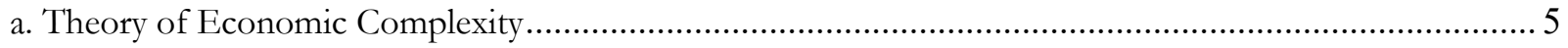

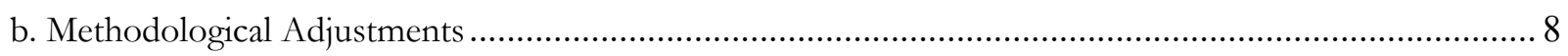

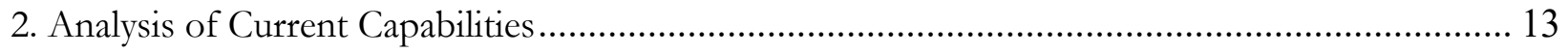

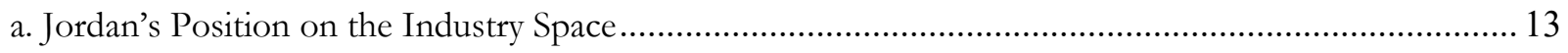

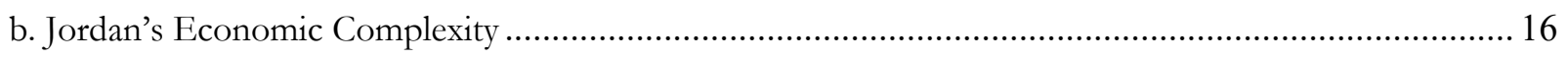

3. Identification of Diversification Opportunities ................................................................ 18

a. Main Objective

4. Prioritization of Diversification Opportunities ............................................................. 23

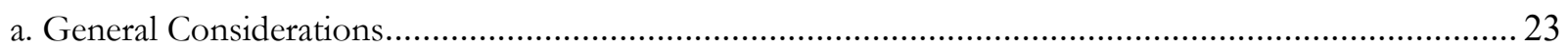

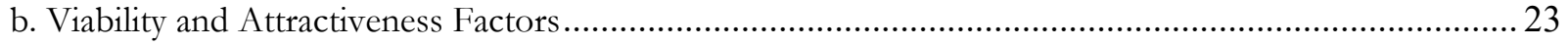

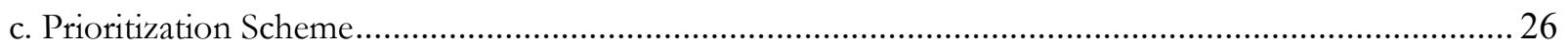

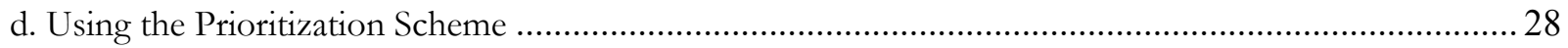

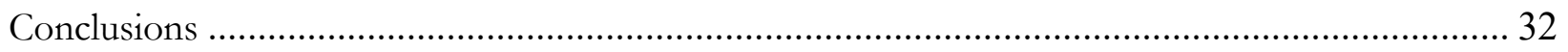

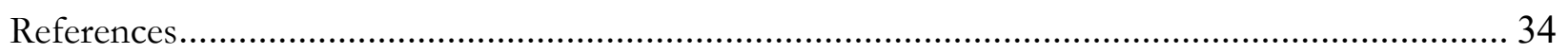

Annex 1: Export Themes and Industries, Jordan ................................................................ 35

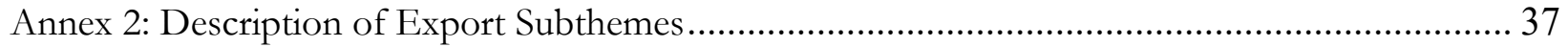

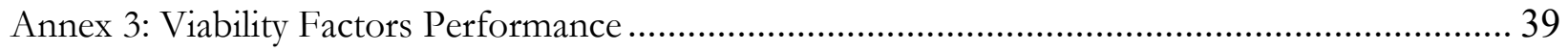

Annex 4: Attractiveness Factors Performance .................................................................... 42

Annex 5: Methodology for Estimating Missing Inputs ......................................................... 45

Annex 6: Methodology for Estimating Foreign Direct Investment .......................................... 46

Annex 7: Industries Excluded from the Analysis after Identification of Export Themes .............. 47

Financial support for this research came from the Open Society Foundations, through a grant to the Center for International Development at Harvard University to provide research support to the Government of Jordan. 


\section{List of Figures}

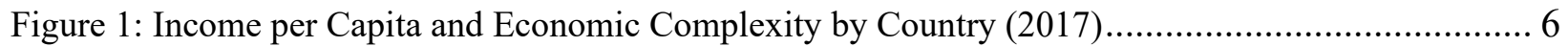

Figure 2: Jordan's Exports by Category (1995-2017) ............................................................... 9

Figure 3: Composition of Exports by Category - Jordan and Benchmark Countries (2017) ................. 10

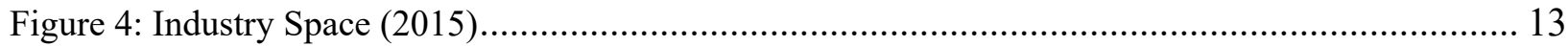

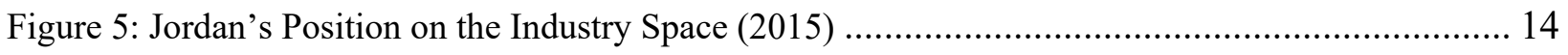

Figure 6: Industry Diversity (2015) - Jordan and Benchmark Countries ..................................... 15

Figure 7: Contribution to Diversity by Category (2015) - Jordan and Benchmark Countries ................ 15

Figure 8: Average Ubiquity Versus Diversity (2015) - Based on Employment by Industry .................. 16

Figure 9: Two Measures of Economic Complexity Index (2015) - Based on Employment by Industry .. 17

Figure 10: Income per Capita and Economic Complexity by Country (2015) - Based on Employment by

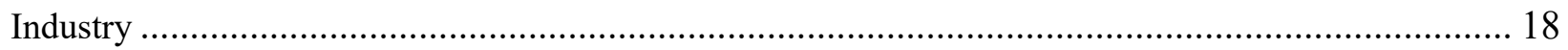

Figure 11: Sector Identification / Validation Process .................................................................... 19

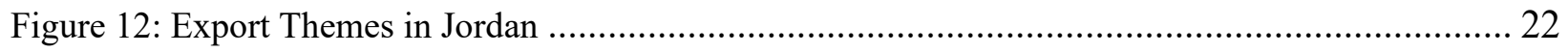

Figure 13: Export Themes in Comparison with Previous Studies ................................................. 22

Figure 14: Viability Factors Performance, Normalized Values - Engineering Services ....................... 27

Figure 15: Attractiveness Factors Performance, Normalized Value - Engineering Services ................ 27

Figure 16: Prioritization Phases of Diversification Opportunities ............................................... 29

Figure 17: Prioritization Phases of Diversification Opportunities - Engineering Services ................... 29

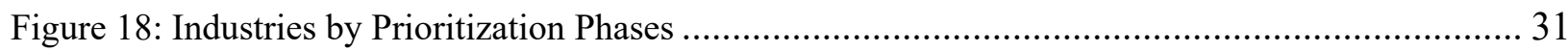




\section{Introduction}

Jordan faces a number of pressing economic challenges: low growth, high unemployment, rising debt levels, and continued vulnerability to regional shocks. After a decade of fast economic growth, the Global Financial Crisis of 2008-09 set off a deceleration. From then onwards, various external shocks have thrown Jordan's economy out of balance and prolonged the slowdown for over a decade. Conflicts in neighboring countries have led to reduced demand from key export markets and have cut off important trade routes. Foreign direct investment (FDI), which averaged $12.7 \%$ of gross domestic product (GDP) between 2003-2009, fell to 5.1\% of GDP over the 20102017 period. Regional conflicts have negatively impacted tourism, provoked a massive influx of migrants and refugees, and interrupted the supply of gas from Egypt - forcing Jordan to import oil at a time of record prices. Failure to cope with a $50.4 \%$ growth in population led to nine consecutive years (2008-2017) of negative growth rates in GDP per capita, resulting in a cumulative loss of $14.0 \%$ over the past decade (2009-2018). Debt to GDP ratios, which were at $55 \%$ by the end of 2009, have skyrocketed to $94 \%$.

Over the previous five years, Jordan has undertaken a significant process of fiscal consolidation. The resulting reduction in fiscal impulse ranks among the largest recorded in the aftermath of the Global Financial Crisis: third only to Greece and Jamaica, and greater that Portugal and Spain. Higher taxes, lower subsidies, and sharp reductions in public spending have, in turn, furthered the recession. Within a context of lower aggregate demand, more consolidation is needed to bring debt-to-GDP ratios back to normal.

The only way to break this vicious cycle and restart inclusive growth is by leveraging on foreign markets, developing new exports and attracting investments aimed at increasing competitiveness and strengthening the external sector. ${ }^{1}$ The theory of economic complexity provides a solid base for identifying opportunities with high potential for export diversification. It pinpoints the existing set of knowhow, skills and capacities as signaled by the goods and services that Jordan is able to produce, and defines existing and latent areas of comparative advantage that can be developed by redeploying them. Service sectors have been growing in importance within the Jordanian economy and will surely play an important role in export diversification. In order to account for that, we have developed an adjusted framework that can include service exports in the diagnostic.

Based on the adjusted framework, this report identifies export themes with a high potential to drive growth in Jordan while supporting increasing wage levels and delivering positive spillovers to the non-tradable economy. The general goal is to provide a roadmap with key elements of a strategy for Jordan to return to a path of high economic growth that is consistent with its emerging comparative advantages.

This report is organized in four sections. Section 1 explains the methodology of economic complexity, including its main concepts, as well as the adjustments that were required to

\footnotetext{
${ }^{1}$ A full analysis of Jordan's recent growth trajectory and the main challenges that the economy faces moving forward can be found in Hausmann et al. 2019.
} 
incorporate the service sector into the analysis. Section 2 describes the structure of the Jordanian economy, identifying its productive capacities and exploring its complexity profile. The third section selects the industries with the highest export potential and groups into themes for investment promotion efforts. In the last section, we develop a system that further filters these themes by viability and attractiveness, in order to prioritize investment promotion and export diversification efforts.

\section{Conceptual Framework}

\section{a. Theory of Economic Complexity}

The theory of economic complexity, introduced by Hausmann, Hidalgo et al. (2014), is based on the premise that the development of products and services not only requires raw materials, labor and machinery, but also, a tacit knowledge of how to combine inputs and run business operations. Tacit knowledge (or knowhow) tends to be the binding constraint for diversifying economic activities in a country, because it's the most difficult factor to transfer. The production of modern goods and services require shared knowhow across teams and organizations, which is acquired by individuals slowly, through experience. Since complex economic activities demand a diverse set of skills, modern economies require that individuals know different things and that markets function in a way that allows firms to organize human capital for production. As a result, the process of economic development is slow because the accumulation of diversified private sector knowhow is necessarily difficult and gradual.

Some products and services incorporate large amounts of tacit knowhow and are the result of complicated interaction networks. In contrast, others incorporate much less knowhow and require simpler networks. In this sense, different products and services can be thought of as "words" whose assembly requires "letters" (knowhow-based capabilities). The production of long and sophisticated words requires many letters, while few are needed to generate short and simple words. Places differ in both the quantity and quality of agglomerated knowhow. While some places have many and very diverse letters, which they can easily combine to form long words; others have very few, which limits the possibility of creating new words. Moreover, the differences in productive capacities caused by uneven "endowments" of letters are further amplified by the fact that the number of words that can be constructed increases exponentially as new letters are acquired. Thus, for example, in the English language, with one letter, "a", only one word can be formed of up to one letter ("a"); with 3 letters, "a", "c" and "t", you can form up to four words of up to three letters ("a", "at", "cat" and "act"); with four letters, "a", "c", "t" and "r", you can form nine words of up to four letters ("a", "at", "cat", "act", "rat", "car", "art", "tar" and "cart"); and with ten letters ( "a", "c", "t", "r", "o," 1 "," g "," s "," n "and" i "), you can form 595 words of up to ten letters. 
Ultimately, places develop the products and services (words) that their agglomeration of knowhow (variety of letters) can support. Therefore, by observing patterns of production across places and time, we can infer and mathematically construct quantitative measures that capture how much knowhow a place possesses (Economic Complexity Index, ECI), and how much knowhow a particular set of goods and services requires (Productivity Complexity Index, PCI). High ECI places support a diverse set of economic activities, including activities that are not common across places. Low ECI places support a low diversity of activities, and those activities tend to be ubiquitous across places. This inverse relationship between diversity and ubiquity is observed empirically across countries, states and cities.

Given that economic complexity reflects the amount of knowhow that is embedded in the productive structure of an economy, the strong correlation between measures of complexity and income is not surprising. Figure 1 shows the relationship between per capita income and economic complexity across all countries of the world.

Figure 1: Income per Capita and Economic Complexity by Country (2017)

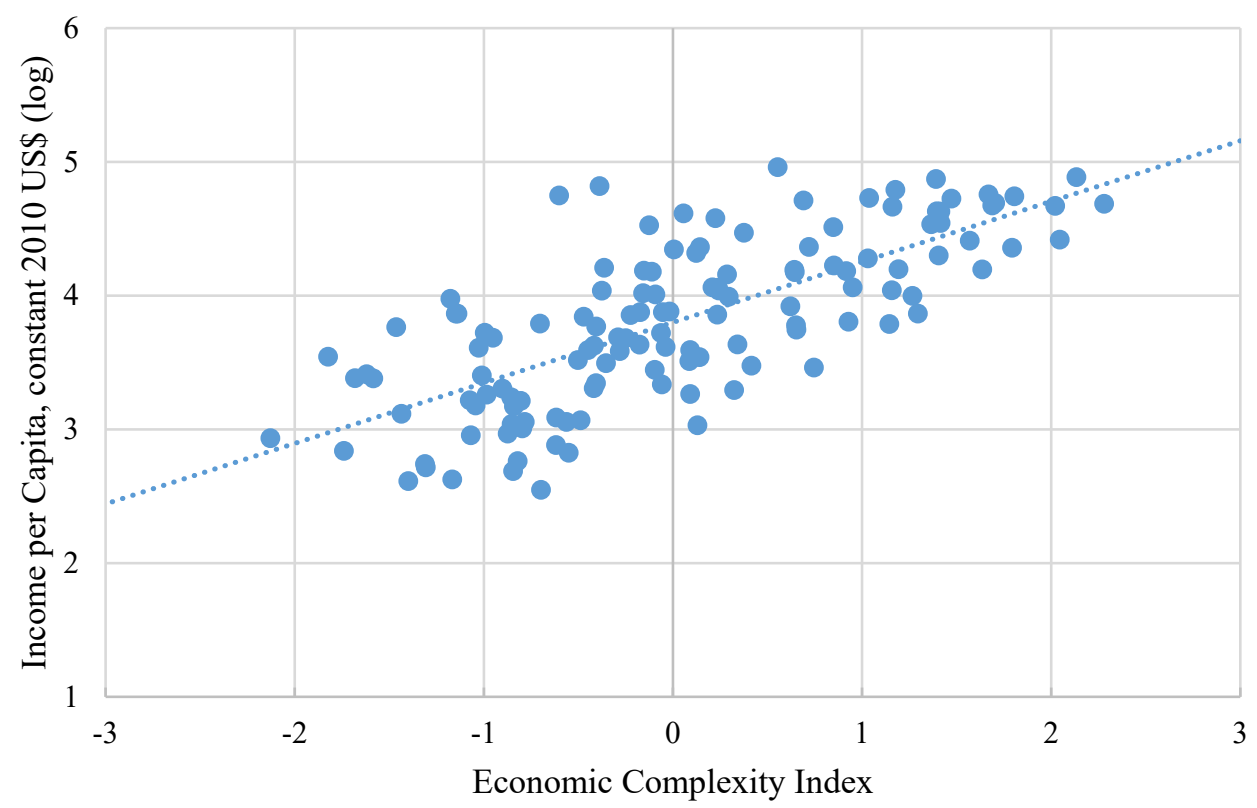

Source: Own calculations based on World Bank WDI and the Atlas of Economic Complexity

Additionally, Hausmann, Hidalgo et al. (2014) found that the prediction errors in Figure 1between a country's income-complexity coordinates and their predicted location on the regression line - are informative of future growth rates. Countries with an economic complexity greater than predicted by their level of income tend to grow faster than countries with higher income than predicted by their current level of economic complexity. Thus, economic complexity is not just a 
symptom or an expression of prosperity: it is a driver. In short, economic complexity matters because it helps explain disparities in countries' levels of income, and, more importantly, because it predicts future economic growth.

The process of economic development involves countries diversifying from the production of simple goods and services to more sophisticated ones, in a sequence often referred to as "structural transformation." Conventional economic theory suggests that a country's fundamentals - namely, its endowments of physical and human capital, labor, and natural resources along with the overall quality of its institutions - determine its pattern of specialization. If this were true, the process of structural transformation would be a passive consequence of changing factor endowments.

In reality, historical examples show that structural transformation has tended to be far from passive. Hausmann and Klinger (2006) show that producing new goods and services is different from producing more quantities of those already produced. Specifically, the assets and capabilities needed to produce one good or service are imperfect substitutes for those needed to produce others, and the degree of substitutability varies. Correspondingly, the probability that a country develops a new industry is related to its existing production capabilities in other similar industries. New capabilities will be more easily accumulated if they can be combined with others that already exist. An implication of this is that a country will diversify by moving from the products and services they already produce to others that require a similar set of assets and knowhow.

Based on this idea, Hausmann and Klinger (2006) proposed a metric of similarity between products. In essence, gage the distance between each pair of products through the probability that countries export both. The collection of all proximities is a network that connects pairs of products based on their tendency to be co-exported by many countries. They refer to this network as the Product Space and use it to study the productive structure of countries. ${ }^{2}$ The location of a country on the Product Space captures information regarding both the productive knowhow that it possesses and the capacity to expand that knowledge by moving into other nearby products. The analysis of a country's position in, and movement throughout, the Product Space has become a common and powerful tool for formulating economic growth strategies. ${ }^{3}$

\footnotetext{
${ }^{2}$ Based on these arguments, the structure of the Product Space is crucial because it affects countries' abilities to move into new products. A highly connected position on the Product Space reflects relatively easier paths to diversification than a sparse position. Hausmann and Klinger (2006) find that the Product Space is highly heterogeneous: some sections are composed of densely connected groups of products whereas others are more loosely connected. This heterogeneity has significant implications for the speed and patterns of structural transformation: the ability of countries to diversify and to move into products that are more complex is crucially dependent on their initial location on the Product Space.

${ }^{3}$ Harvard CID's Growth Lab developed a free, online tool for Product Space analysis of any country in the world: See http://atlas.cid.harvard.edu/
} 


\section{b. Methodological Adjustments}

The complexity metrics described in the previous section have traditionally been calculated using international trade data. Given the lack of currently available standardized export data for services with sufficient industrial disaggregation at an international level, these metrics have been exclusively focused on goods so far, and have excluded the service sector altogether. Such analyses have shown that Jordan has lost economic complexity over the past two decades, resulting in limited and problematic "nearby" diversification opportunities moving forward. ${ }^{4}$

However, services are of great importance to the Jordanian economy and also require a significant agglomeration of knowhow. Many service exports are also non-intensive on factors that are expensive and scarce in Jordan, such as electricity and water, and can potentially be less vulnerable to trade disruptions in the region than goods exports. From 1995 to 2008, Jordanian service exports grew steadily from US\$ 1.7 billion to US\$ 4.8 billion. Despite the strong impacts of the 2008-2009 Global Financial Crisis on the global economy, Jordanian service exports only experienced a minor hiccup thereafter, and eventually grew to US\$ 7.1 billion in 2014 (Figure 2). Service exports continued to expand from 2009 to 2014 while exports of goods stagnated. By 2016, services accounted for nearly $45 \%$ of total Jordanian exports, a proportion that is relatively higher than that of benchmark countries (Figure 3).

In order to account for this reality, the Growth Lab at Harvard University developed and applied a tool to perform complexity analysis on Jordan which includes services. Previous efforts to incorporate the service sector within the complexity framework were made by Hausmann, Morales and Santos (2017) in Panama, taking advantage of the comprehensive nature of the population census in that country. Other attempts to represent a service-inclusive product space can be found in the Colombian Atlas of Economic Complexity ${ }^{5}$ and the Mexican Atlas of Economic Complexity. ${ }^{6}$ These online tools have supported numerous efforts to identify productive capabilities at the sub-national level, and uncover the most attractive opportunities for structural transformation.

Since Jordan lacks publicly available databases with the granularity required to deploy the economic complexity algorithms, we have used the Dun \& Bradstreet (D\&B) database (2015) instead. In doing so, some significant adjustments and adaptations were made to the original Product Space methodology.

The adjusted methodology estimates a place's (country, state, city) productive capacities according to its relative intensity of employment in different industries. The employment absorption capacity

\footnotetext{
${ }^{4}$ See Jordan's Country Profile on the Atlas of Economic Complexity and the Jordan Strategy Forum's two-part study: $\underline{\text { Part I and Part II }}$

${ }^{5}$ http://datlascolombia.com

${ }^{6}$ https://datos.gob.mx/complejidad/
} 
varies significantly between industries, so absolute employment by industry may reveal little information regarding a particular place's competitive advantages. Therefore, instead of inferring the existence of productive capacities and knowhow based on the sheer size of employment by industry, we use a relative measure that ponders the share of employment by industry in the place, vis-a-vis its share of total employment worldwide. ${ }^{7}$

Figure 2: Jordan's Exports by Category (1995-2017)

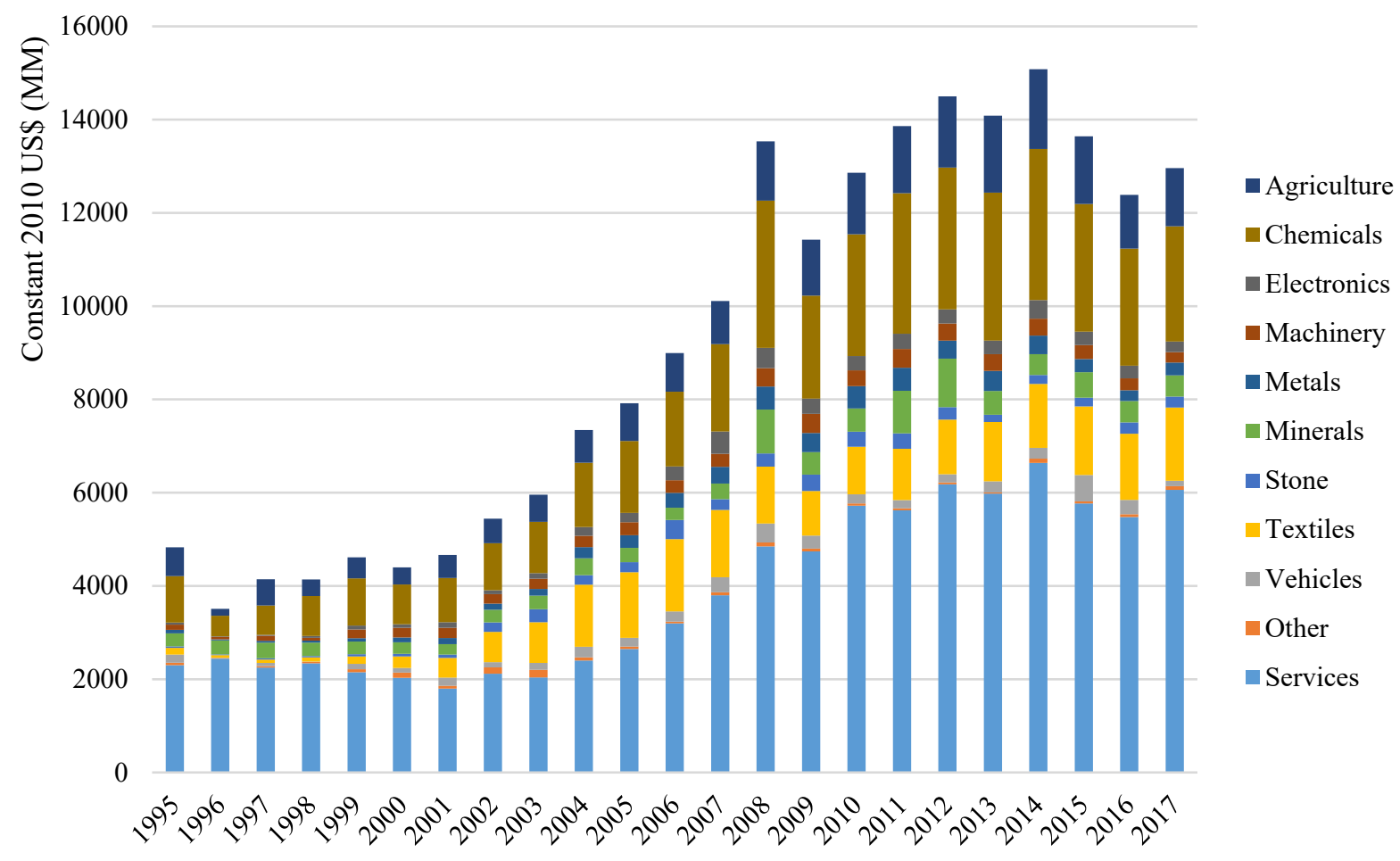

Source: Own calculations based on the Atlas of Economic Complexity

${ }^{7}$ The methodology implicitly assumes that the combination of capital and labor used to develop a certain industry is relatively similar in all countries. 
Figure 3: Composition of Exports by Category - Jordan and Benchmark Countries (2017)

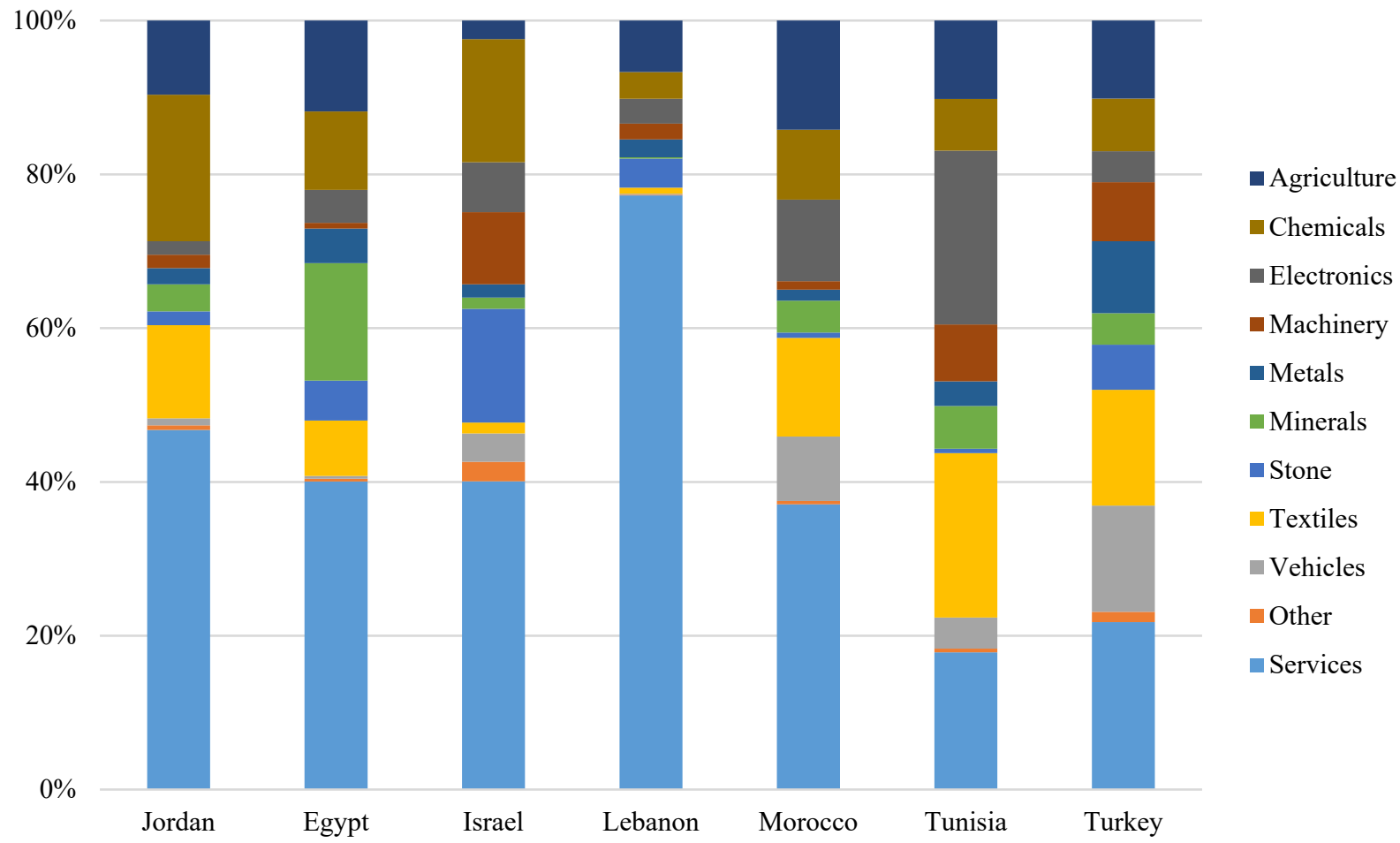

Source: Own calculations based on the Atlas of Economic Complexity

More precisely, the complexity methodology uses the concept of revealed comparative advantage (RCA), which measures the relative importance of a sector in a particular place. Following the methodology of Balassa (1964), RCA is usually calculated as the ratio between the share of a sector in a place's exports and the share of that sector in world trade. If this relationship is greater than 1 , it is said that the place has a "revealed comparative advantage" or RCA in that sector, which is equivalent to saying that the sector in that place has developed more intensively than in the rest of the world.

In order to include services within this context, we have based the RCA calculation on employment data by industries. Specifically, the calculation formula is as follows:

$$
R C A_{i, c}=\frac{E_{i, c} / \sum_{i} E_{i, c}}{E_{i, w} / \sum_{i} E_{i, w}}
$$

where $E_{i, c}$ is employment in industry $i$ in country $c$, and $E_{i, w}$ is worldwide employment in industry $i$ (sum of all countries for which information is available).

Complexity metrics of industries, as in the original methodology, are estimated at an international level according to the ubiquity and the diversity of the places that they are intensive in. The only difference is that, in our modified approach, RCAs are based on shares of employment instead of 
exports. In this way, complex industries are those in which relatively few places, and places that are highly diversified, show a high relative intensity of employment $(R C A \geq 1){ }^{8}$

Likewise, methodological adjustments were necessary to adapt the concept of the Product Space to include services. As described above, the original indicator proposed by Hausmann and Klinger (2006) measures proximity between pairs of products through the probability that countries export both. The network defined in this way has been used to study a country's productive structure and its abilities to move into new products. For all its benefits, this methodology has a great disadvantage: it does not include the service sector. In order to address this, we developed an alternative way to measure proximity that allows for the inclusion of services and called the resulting network the "Industry Space." Our methodology computes the relation between pairs of industries through the probability of co-production (as expressed by RCA $\geq 1$ ). Given the high granularity of the D\&B database, proximity can be calculated at various levels of aggregation, providing complementary indicators.

At the most basic level of aggregation, given available data, proximity can be measured at the establishment level. Proximity at this level of aggregation is estimated through the NoiseCorrected approach developed by Coscia and Neffke (2017). ${ }^{9}$ The proximity measure based at the establishment-level is of a more rigorous nature, as it requires that a pair of nearby industries , involve similar capabilities comprised within the same firm. However, it is usually not in our interest to understand how establishments diversify, but rather how places (countries, states, cities) do. In this sense, our metric - as described above - allows for the possibility that goods and services require similar capacities (letters) even if they are produced in different establishments.

Measuring proximity at the country-level (the broadest level of aggregation), might be subject to spurious co-relations, including cases where co-location occurs purely because of demand factors. In order to identify co-production patterns at a country level, the productive capacities of the different countries in the world need to be estimated. In other words, the methodology needs to assess which industries each country "participates" in. As previously noted, this is estimated according to their relative intensity of employment. ${ }^{10}$ Since the database includes information

\footnotetext{
${ }^{8}$ A more detailed explanation of how to calculate the complexity of different products (industries) can be found in Hausmann, Hidalgo et al. (2014), Technical Box 2.1.

${ }^{9}$ The instances in which an establishment participates in two industries $-i$ and $j-$ at the same time are added to obtain $N_{i j}$. If this number were divided by the total number of instances in which industry $i$ (or j) is co-produced with another industry within the same establishment, a conditional probability similar to the one that underlies the Product Space would be obtained. However, certain industries may be so prevalent that they are co-produced by many other industries, leading to spurious connections. In order to eliminate these, $N_{i j}$ is divided by an estimation of the expected number of co-occurrences between industries $i$ and $j$. The ratio shows how unexpectedly high the observed number of co-occurrences is. When it equals one, it means that industries $i$ and $j$ are co-produced in the same establishment as frequently as expected.

${ }^{10}$ A country is said to participate in a certain industry if it employs more than its "fair share" in it. In other words, when it shows an RCA $\geq 1$. Once RCAs have been calculated and the industries in which each country "participates" have been identified, proximity can be measured through the minimum conditional probability that a country that participates in industry $i$ also participates in industry $j$, in other words, that both activities are carried out intensively within the same country. Since conditional probabilities are not symmetric, the minimum probability of industry $i$,
} 
about the geographic location of establishments and the number of employees they have, it is possible to aggregate and calculate total employment for every industry at a country level.

Regardless of the level at which the co-production patterns are measured, the logic behind these indicators is consistent with the underlying premises of the Product Space. Two industries are "nearby" on the Industry Space if evidence shows that they are manufactured (or rendered, in the case of services) within the same physical space (be it a country, state, city, firm, or establishment) with a relatively high frequency. As with the original Product Space, the methodology does not directly identify all "letters" required by each industry, which would involve having a comprehensive understanding of every single one of their productive processes. Instead, it uses an indirect approach that assumes that if two industries tend to be co-produced very often, this must mean that they require similar capabilities.

Figure 4 shows the Industry Space calculated using proximities measured at an establishment level. Here, nodes represent individual industries and edges connect those that are relatively similar. The different colors indicate the broad sector to which each industry belongs, which tend to cluster. It is important to note that despite the adjustments, this methodology shares two important characteristics with the original: The first is that the economic complexity of a place is predictive of its level of income. Secondly, the initial positioning on the Industry Space of a place is informative of its future diversification opportunities.

given industry $j$, and vice versa, is taken to reduce the likelihood that the relationship is false. It is worth mentioning that we implicitly assume that countries do not participate in those industries in which they show an RCA $<1$, which also helps alleviate the problem of potential spurious connections between industries. 
Figure 4: Industry Space (2015)

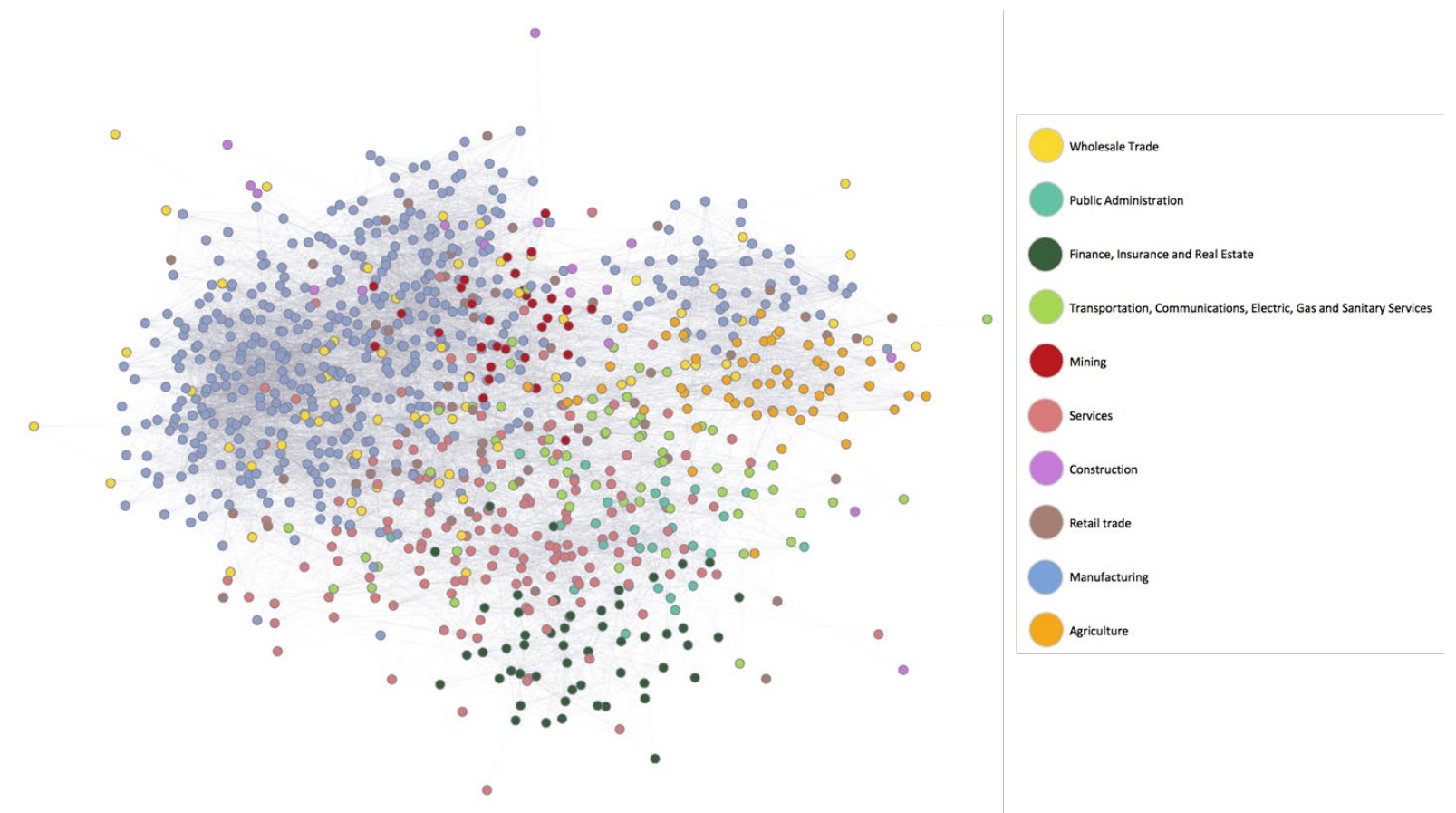

Source: Own calculations based on Dun \& Bradstreet (2015)

\section{Analysis of Current Capabilities}

\section{a. Jordan's Position on the Industry Space}

The Industry Space for Jordan is shown in Figure 5, where the colored circles represent the industries in which Jordan has a revealed comparative advantage (RCA $\geq 1$ ), and the uncolored circles represent other industries absent in Jordan $(\mathrm{RCA}<1)$. In general, it is possible to conclude that Jordan's Industry Space is somewhat sparsely populated and concentrated in manufacturing and wholesale trade. Although the country's presence on the Industry Space is largely represented by these two categories, in relative terms, Jordan also exhibits a high presence of other industries such as public administration; transportation, communications and public utilities; and finance, insurance and real estate. 
Figure 5: Jordan's Position on the Industry Space (2015)

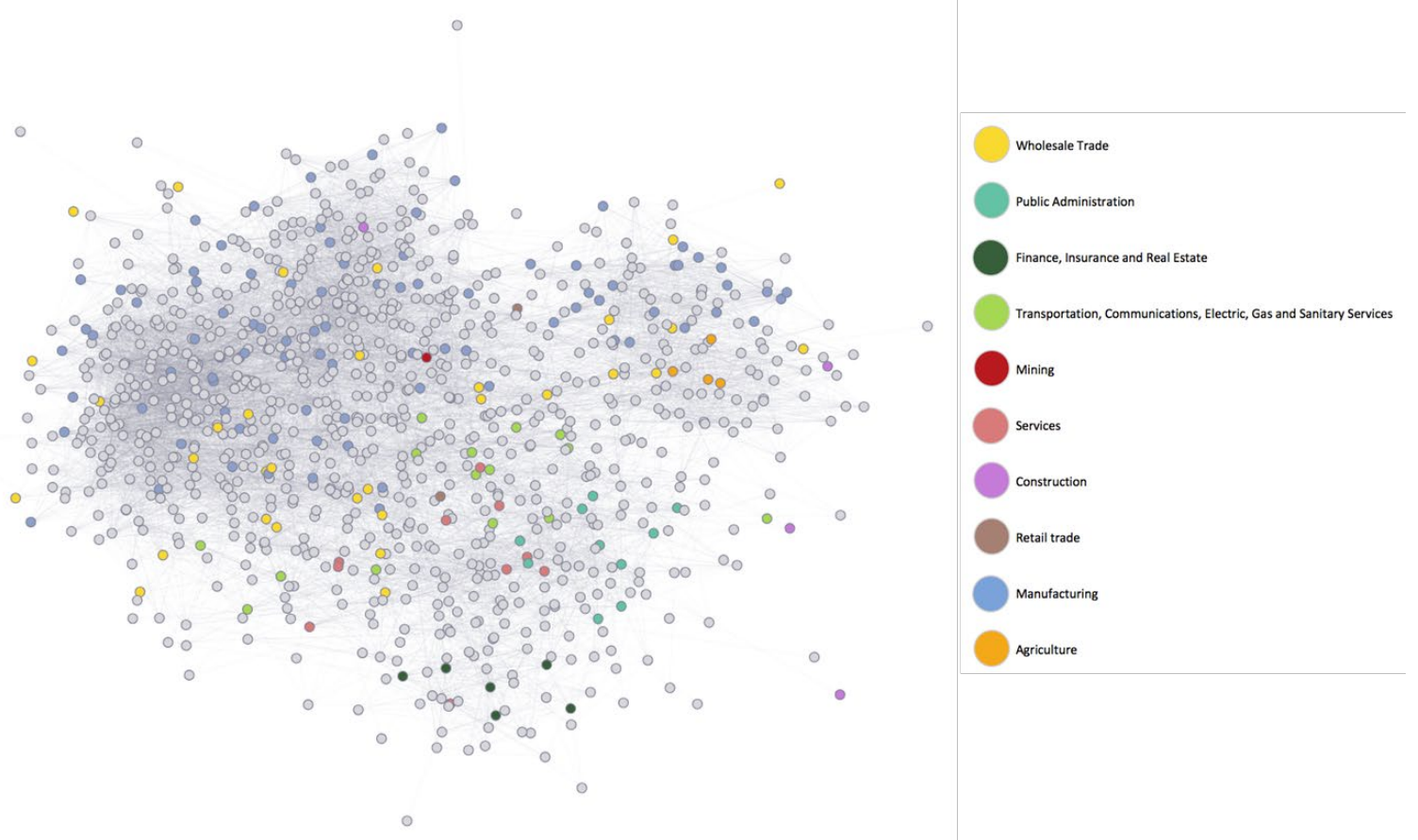

Source: Own calculations based on Dun \& Bradstreet (2015)

Figure $6^{11}$ shows the industry diversity - that is, the number of industries in which a country exhibits a high relative intensity of employment - for Jordan, as well as for a group of benchmark countries. Jordan, with a diversity of 178 , ranks second-to-last among the benchmark countries and is at a fair distance from countries like Tunisia and Turkey, whose diversity is greater than $250 .^{12}$

\footnotetext{
${ }^{11}$ The results shown in figures 6 and 7 should be taken with caution. The correlation between the sectoral composition of employment taken from the census data, and information taken from the D\&B database, is relatively low for all the benchmark countries, with the exception of Tunisia (for the UAE it could not be calculated). This raises some doubts regarding the representativeness of D\&B for these countries.

${ }^{12}$ The results of this calculation are very similar when the diversity of exports is measured using the goods-based measure. Jordan is among the least diverse countries within the comparison group, and ranks far behind the most diverse.
} 
Figure 6: Industry Diversity (2015) - Jordan and Benchmark Countries

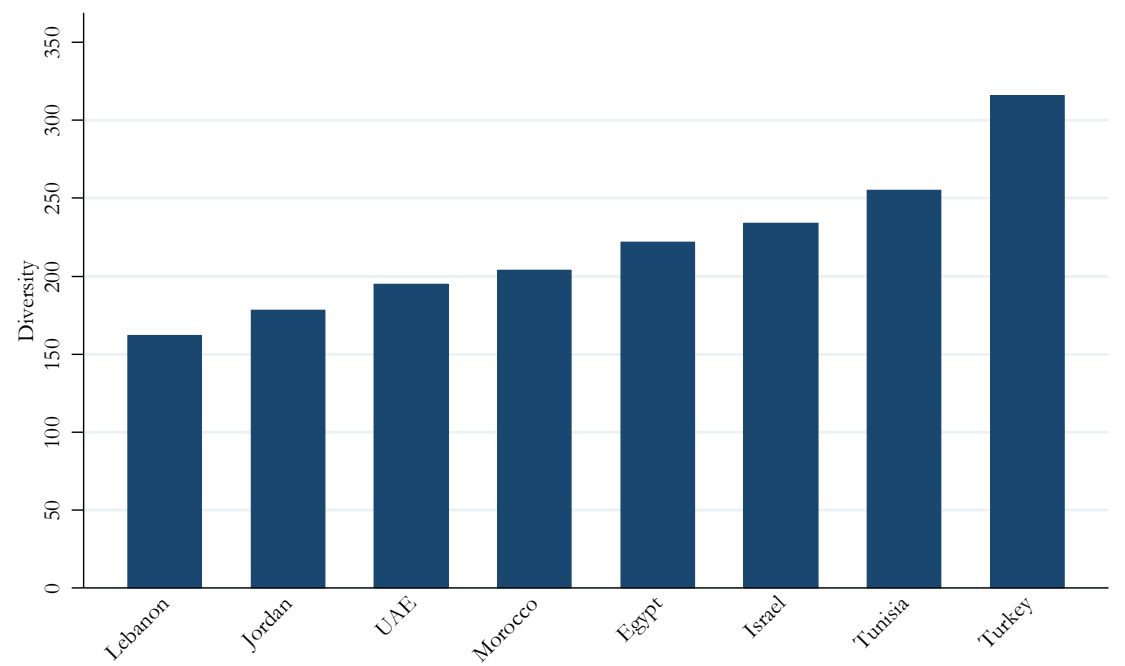

Source: Own calculations based on Dun \& Bradstreet (2015)

Meanwhile, Figure 7 shows the share (in percentage points) that each sector represents within the diversity of the benchmark countries, highlighting Jordan's position in red. The number shown in each column corresponds to Jordan's ranking among this group of countries in each sector. The results indicate that even though manufacturing accounts for roughly half of Jordan's diversity, the country's diversity in manufacturing is not particularly high in comparison to benchmark economies. In the case of the public administration; transportation, communications and public utilities; and finance, insurance and real estate sectors, Jordan ranks first or second in diversity among the group.

Figure 7: Contribution to Diversity by Category (2015) - Jordan and Benchmark Countries

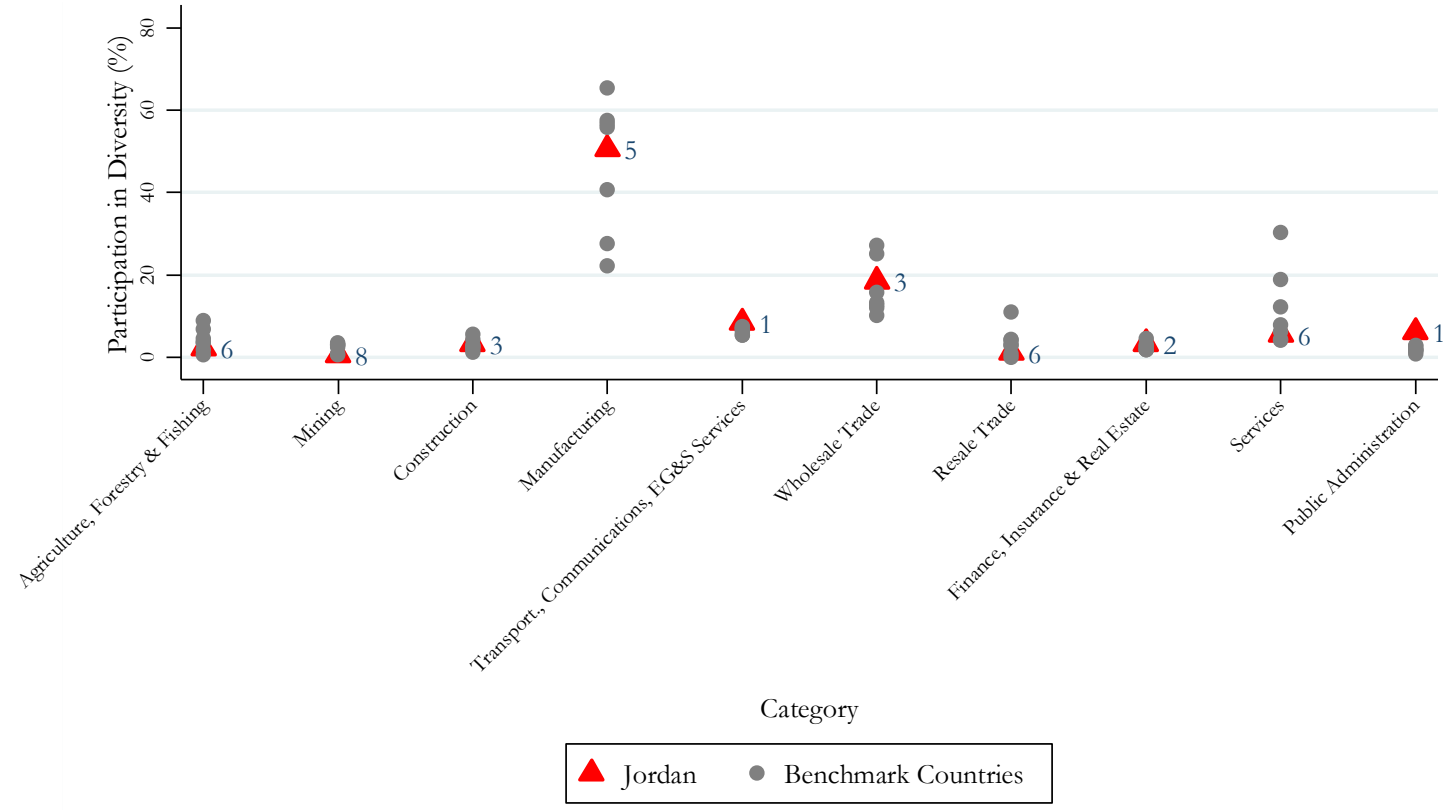

Source: Own calculations based on Dun \& Bradstreet (2015) 


\section{b. Jordan's Economic Complexity}

The ECI index captures more than just the diversity of a place's economic activities; it also mirrors a place's level of economic sophistication - a reflection of the total supply and diversity of knowhow and productive capabilities in a place. The notion of "sophistication" used here does not derive from a direct evaluation of the production processes of the different industries. Rather, it is an indirect measure that infers that the production of a good requires a significant variety of knowhow if few places produce it (the product has low ubiquity), and if the places that produce it tend to produce a lot of different things (high diversity). For this analysis, we continue to use the term Product Complexity Index (PCI) to refer to the inferred sophistication of individual goods and services. The ECI measure is calculated as the average complexity of all the products and industries in which a place displays an RCA greater than or equal to one, and therefore captures an overall measure of sophistication of the economy.

Figure 8 plots the diversity and average ubiquity of the existing industries (RCA $\geq 1)$ in different countries, highlighting Jordan (in red) and its benchmark countries (in blue). Relative to the comparison group, Jordan shows a low diversity, as previously shown in Figure 6. Figure 8 also shows that the industries present in Jordan are more ubiquitous than in the benchmark countries (a higher average ubiquity for the industries present), with the exception of Lebanon. Additionally, the industries present in Jordan are slightly more ubiquitous than would be expected based on Jordan's diversity - that is, Jordan is positioned above the regression line.

Figure 8: Average Ubiquity Versus Diversity (2015) - Based on Employment by Industry

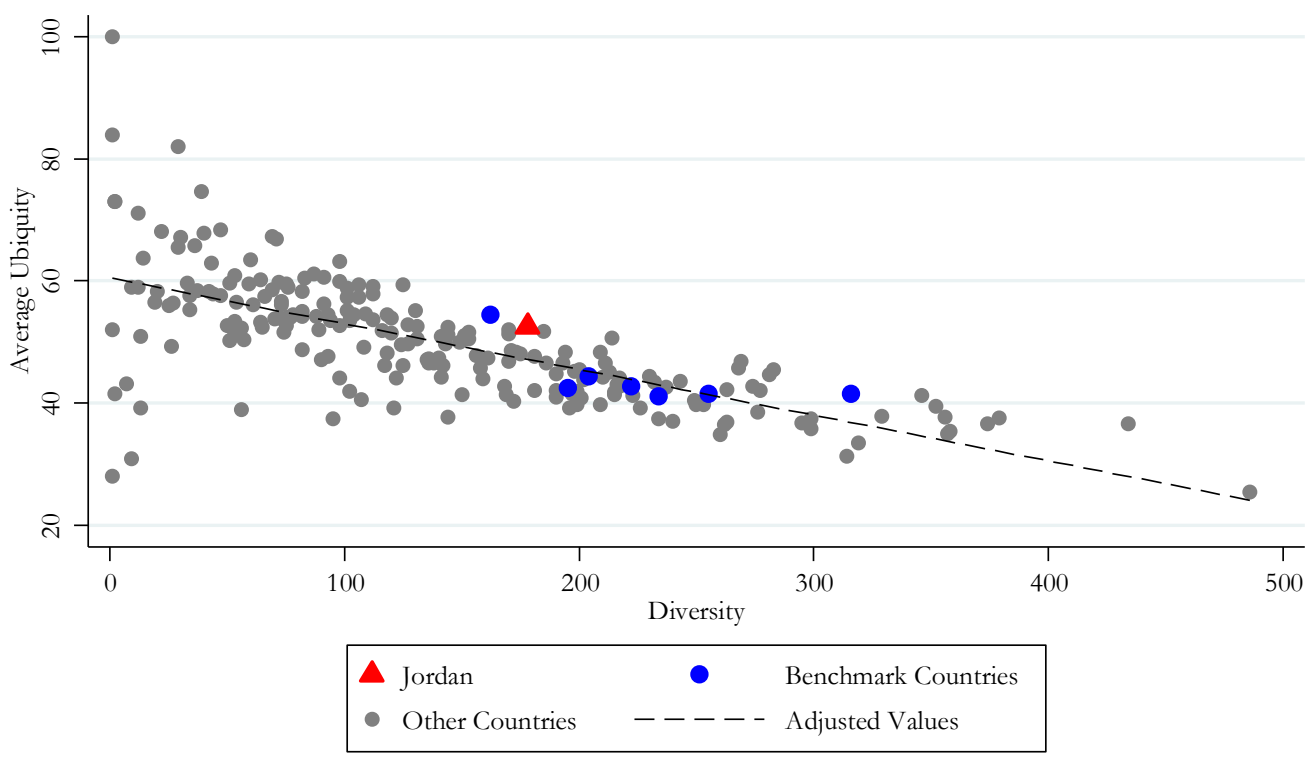

Source: Own calculations based on Dun \& Bradstreet (2015) 
Based on the above findings, it is not surprising that Jordan exhibits a low ECI. Figure 9 displays two versions of the ECI for all countries - one that includes all possible industries and another that only considers those that are relatively tradable. ${ }^{13}$ In both cases, Jordan is poorly ranked relative to its comparable countries and, more broadly, to the rest of the world. Moreover, as shown by Figure 10, Jordan shows an ECI index that is lower than what can be expected for its income per capita level. Unfortunately, given data limitations, this exercise could not be duplicated for various points in time. Therefore, we cannot evaluate if Jordan has become more or less complex over time when services are included in the ECI measure.

Figure 9: Two Measures of Economic Complexity Index (2015) - Based on Employment by Industry

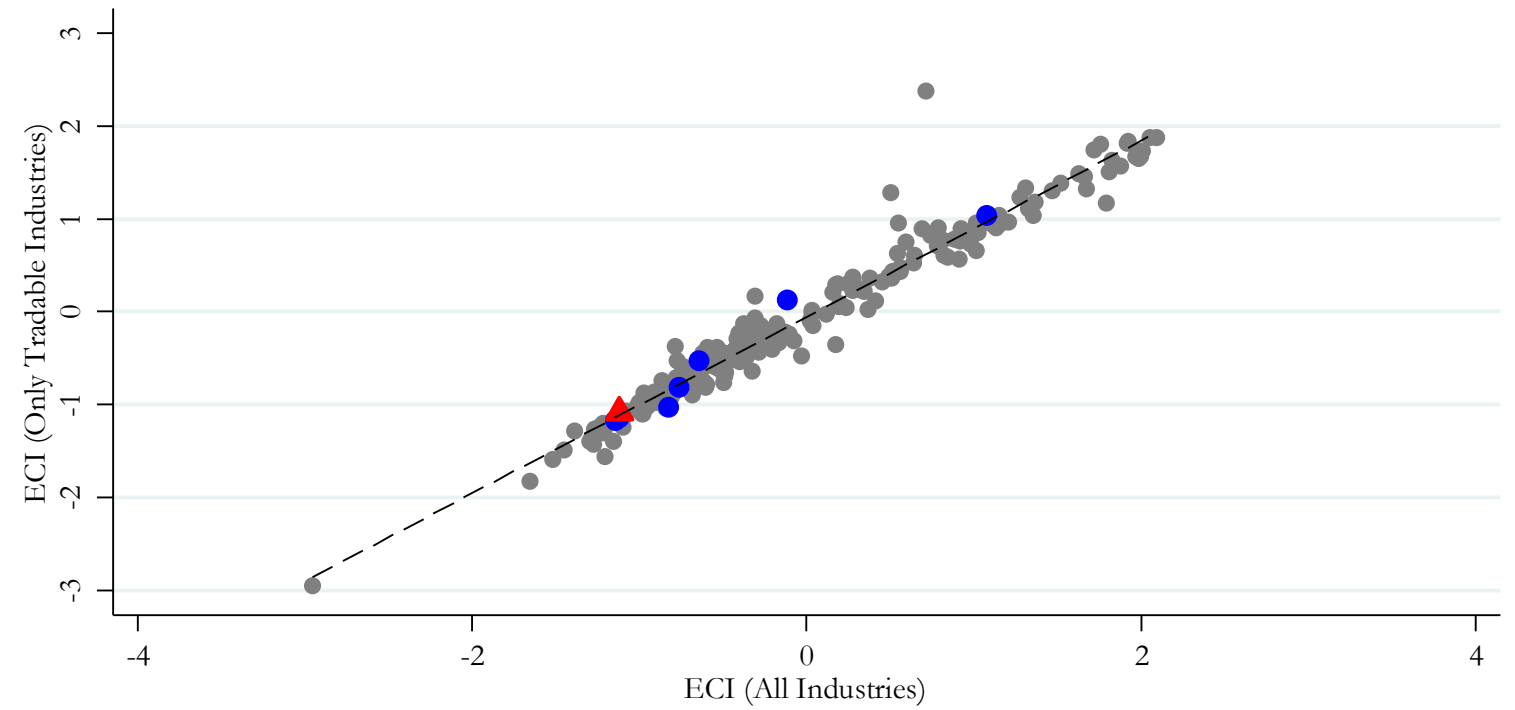

\begin{tabular}{|c|c|c|}
\hline$\triangle$ Jordan & 0 & Benchmark Countries \\
\hline - Other Countries & ----- & Adjusted Values \\
\hline
\end{tabular}

Source: Own calculations based on Dun \& Bradstreet (2015)

\footnotetext{
${ }^{13}$ This adjustment is provided in order to address the concern that the relative intensity of employment may not be an adequate measure of the competitive advantages of countries in the case of non-tradable industries. For these purposes, when calculating the second version of the Economic Complexity Index, some industries are excluded from the analysis, such as those belonging to wholesale trade, resale trade and public administration.
} 
Figure 10: Income per Capita and Economic Complexity by Country (2015) - Based on Employment by Industry

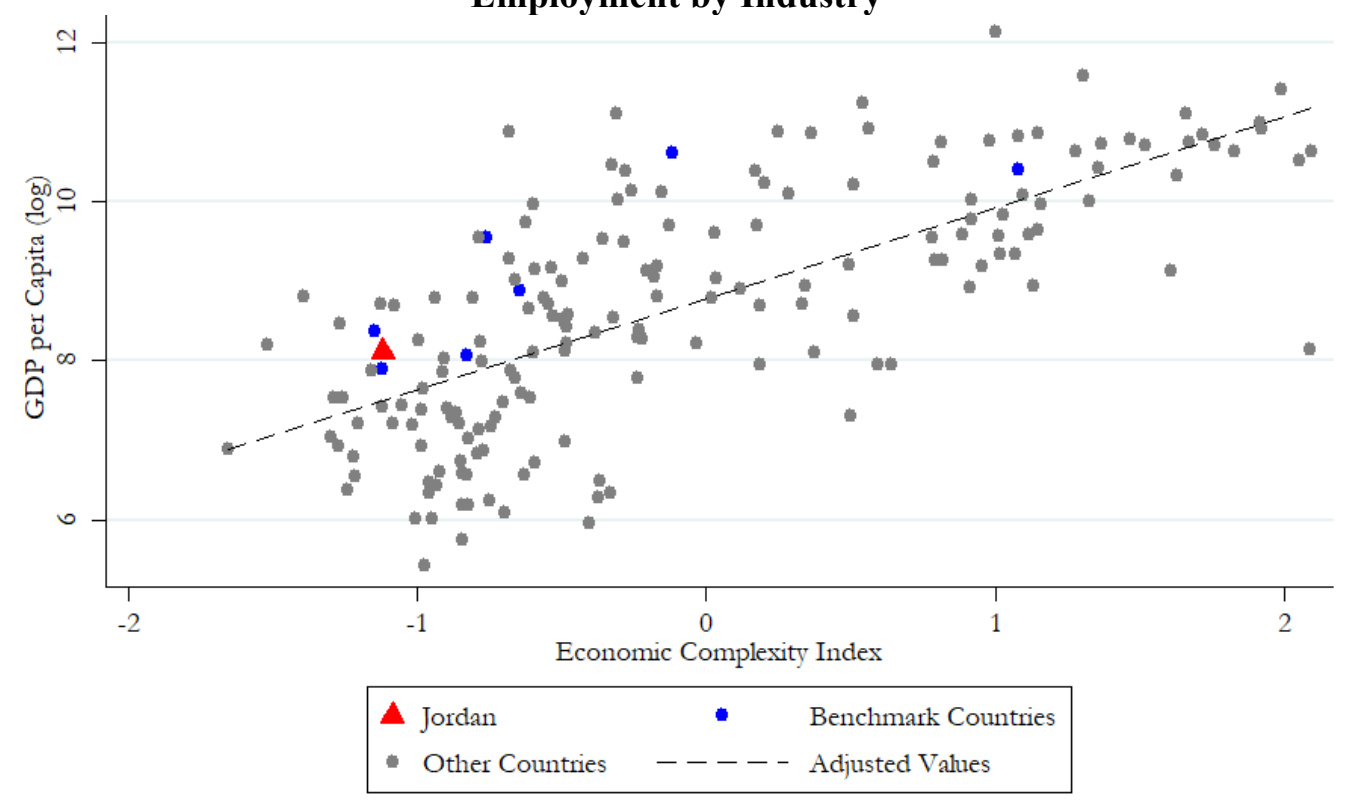

Source: Own calculations based on Dun \& Bradstreet (2015)

\section{Identification of Diversification Opportunities}

\section{a. Main Objective}

As is the case with the Product Space, a country's position on the Industry Space, regardless of its ECI, is informative of what potential new industries are most related to its current capabilities and knowhow. Given Jordan's low ECI, it is especially important that policymakers be strategic in exploring which economic activities they target for development through investment promotion efforts. The main goal of this section is to outline a roadmap for export growth and diversification that builds on Industry Space information. Ultimately, policymakers should use an iterative and dynamic process to target investment promotion and export development efforts, and should interact with many stakeholders - especially with the private sector - to incorporate a variety of perspectives and to implement shared strategies. This exercise is meant to serve as a point of departure for building such a process by rigorously identifying key opportunities for export growth on both the intensive and extensive margins, based on Jordan's position on the Industry Space. The following section of this paper builds on this analysis by introducing a framework and an applied tool that the Government of Jordan can use to further prioritize its actions. 


\section{b. Sector Identification Process}

Jordan's position on the Industry Space reveals existing and latent areas of comparative advantage that could be developed by redeploying the knowhow, skills and capacities that are already available in the country. This section systematically filters industries based on complexity variables, in order to identify export themes that have the highest potential to drive growth in Jordan while supporting increasing wage levels and delivering positive spillovers to the nontradable economy. The specific process that was followed to identify and prioritize high-potential industries is summarized in Figure 11 and explained in detail below. It relies on the tenets of economic complexity, which offers analytical rigor and impartiality. We first reduce the over 1,000 industries in the Industry Space down to the 119 that are most strategic, and then group these strategic industries into eight strategic export themes.

Figure 11: Sector Identification / Validation Process

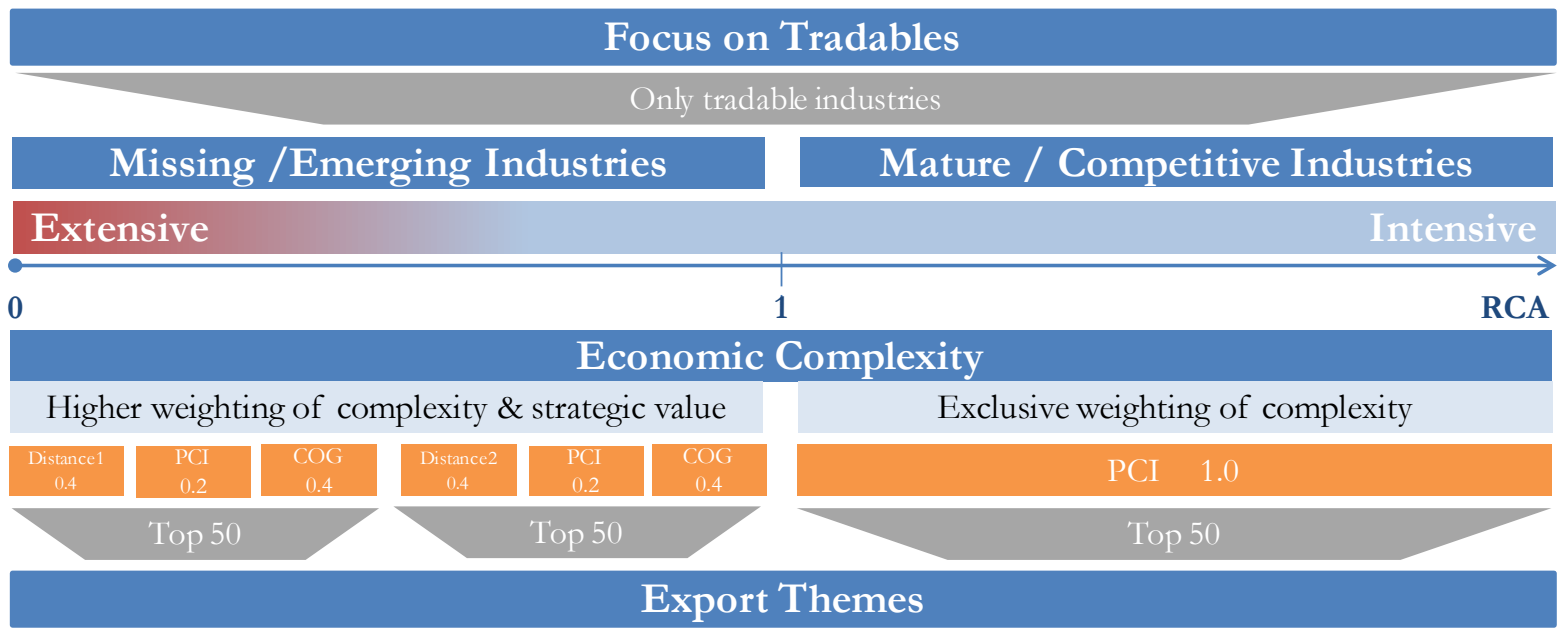

Only industries that can be grouped into an export theme

First, the process filters out those industries that can be regarded as primarily non-tradable, ${ }^{14} \mathrm{a}$ focus that is far from arbitrary. Jordan faces a structural shortfall in its balance of payments, which results in a non-tradable economy that is demand-constrained and where growth in demand for non-tradable goods and services is limited by the pace of export growth. Within a context of fiscal consolidation, the only way to resume growth and employment creation is by growing and diversifying exports. An increase in exports would help to relax balance of payments constraints

\footnotetext{
${ }^{14}$ The identification of which industries are primarily non-tradable is an approximation. For the purposes of this work, the industries belonging to the Wholesale Trade, Resale Trade, and Public Administration divisions (1-digit SIC classifications) are considered as non-tradable. So are the ones belonging to the following major groups (2-digit SIC classifications): Personal Services, Local \& Interurban Passenger Transit, Real Estate, Membership Organizations, Social Services, Private Households, and Postal Service. All other industries (apart from Federal Reserve Banks) are regarded as tradable.
} 
and would lead to higher domestic demand for non-tradable industries, where most jobs can be found.

Once the "tradable" pool of industries is identified, the process applies separate rules to identify two sets of promising industries: those that already have a strong presence in the country that can support wage growth (the intensive margin), and those that are absent or exist with a low intensity but which build on the knowhow and productive capabilities that Jordan already has (the extensive margin). In terms of the conceptual and methodological framework used here, the first type of industries is a subset of those in which Jordan has a high relative employment intensity (RCA $\geq$ 1), while the second type is a subset of industries in which Jordan has a low or non-existing employment intensity $(\mathrm{RCA}<1)$.

The selection of strategic industries is based on economic complexity metrics - Distance, Product Complexity Index (PCI), and Complexity Outlook Gain (COG) - and is different for the intensive and extensive margins. The Distance measure indicates how close a "nearby" industry is to industries already present in the country. ${ }^{15}$ As discussed previously, the PCI indicates how complex or sophisticated a certain industry is. The COG measures the extent to which a particular industry would pave the way for other, more complex industries by improving Jordan's position on the Industry Space. COG effectively captures how much closer an industry would bring Jordan to other complex industries. ${ }^{16}$ All other things being equal, out of two industries with the same Distance and PCI, the one with a higher COG would be more strategic. While PCI and COG tend to be positively correlated, there tends to be negative correlation between Distance and each of these indicators in developing economies. This reflects an important trade-off: the most complex industries and those with the best strategic positioning tend to be further away from existing capabilities, while less complex industries tend to be closer. ${ }^{17}$

In view of this trade-off, the process aims to balance out these different considerations by assigning positive weights to three metrics. On the intensive margin, only the PCI variable is needed because distance and COG are effectively zero for industries where Jordan already has an intensive presence. The process simply selects the 50 industries with the highest PCI values among those in which Jordan already has a presence. On the extensive margin, positive weights are given to all three complexity variables. A weight of 0.4 is applied to Distance, while the remaining 0.6 weight is applied to PCI (0.2) and COG (0.4). This selection of weights assigns a greater combined

\footnotetext{
${ }^{15}$ Specifically, the Distance of an industry is the sum of the proximities connecting that industry to all the industries in which the location is not currently intensive. Formally, for industry i and country c, the distance is:

$d_{c i}=\sum_{j}\left(1-M_{c j}\right) \theta_{i j} / \sum_{j} \theta_{i j}$, where $M_{c j}=\left\{\begin{array}{l}0 \text { if } R C A_{c j}<1 \\ 1 \text { if } R C A_{c j} \geq 1\end{array}\right.$ and $\theta_{i j}$ is the proximity between industries $i$ and $j$.

${ }^{16}$ Complexity outlook gain is defined as: $C O G_{c i}=\sum_{j} \theta_{i j} / \sum_{k} \theta_{k j}\left(1-M_{c j}\right) P C I_{j}$, where $\mathrm{i}, \mathrm{j}$ and $\mathrm{k}$ are industries.

${ }^{17}$ This negative relationship can be thought of as a risk-return curve. That is, the country may have less chance of success when trying to promote the development of more sophisticated industries, because it requires capabilities that are further away from its initial stock. However, if the country's efforts are successful, rewards are greater because it will have gained greater complexity and/or improved its long-term strategic positioning.
} 
relevance to PCI and COG because of Jordan's relatively low economic complexity and its need to diversify fast in order to support income growth.

Given the granularity of the D\&B data, proximity between industries, and ultimately Distance, can be measured based on co-production patterns at the establishment or country level, as discussed previously. ${ }^{18}$ For this reason, the methodology uses both constructions of the Distance measure. On the extensive margin, 50 industries are selected using establishment-level Distance and 50 industries are selected using country-level Distance.

At this point, the 146 industries that emerged as strategic, regardless of whether on the intensive or extensive margins, were classified into groups of related industries. ${ }^{19}$ It turned out that eight groups captured 119 of the strategic industries. These eight groups were therefore considered to represent strategic "export themes," and any strategic industries that were not mapped to one of the themes were dropped from the process at this point (the industries that were dropped from the process are detailed in Annex 7). The logic behind this step is that government resources would be more effectively used if targeted toward collections of industries as opposed to very specific industries.

\section{c. Export Themes}

The 119 strategic industries that emerged from this analysis, grouped into eight themes, provide a basic roadmap for structural transformation and export diversification for Jordan over the next several years. These strategic export themes, shown in Figure 12, are the following: Business, IT and Professional Services; Education Services; Healthcare Services; Tourism; Creative Industries; Transport; Construction; and Agriculture and Food. Annex 1 shows the different industries that make up each of these themes, grouped into narrower thematic sub-areas. A description of these thematic sub-areas is included in Annex 2.

18 Pending further research to determine which construction has more explanatory power over subsequent diversification. This would require a panel dataset, which is currently unavailable.

${ }^{19}$ Note that this is lower than 150 because of 4 products appearing in the top 50 on the external margin regardless of which distance measure was used. 


\section{Figure 12: Export Themes in Jordan}

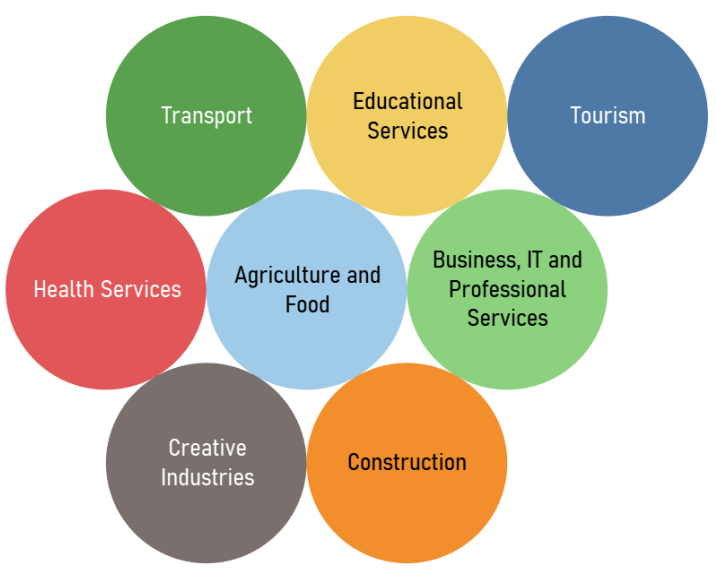

It's important to note that most of these export themes were also identified in a previous government vision document ("Jordan 2025," 2014) and a previous Investment Promotion Strategy for the Jordan Investment Commission (JIC), 2016. The most noteworthy exceptions are Creative Industries and some specific opportunities we identified in the agriculture sector. Meanwhile, our complexity analysis does not include Chemicals or Life Sciences as a theme. ${ }^{20}$ Side-by-side comparisons between strategic industries are shown in Figure 13.

Figure 13: Export Themes in Comparison with Previous Studies

\begin{tabular}{lcclll} 
JIC (2016) & & & Jordan 2025 (2014) & Harvard CID (2019) \\
\hline Sector / Priority & High & Med & Sector & Sector \\
\hline Business Services & $\checkmark$ & & Digital / Business Services & $\begin{array}{l}\text { Business, IT and Professional } \\
\text { Services }\end{array}$ \\
\hline Chemicals & $\checkmark$ & & & $\begin{array}{l}\text { Business, IT and Professional } \\
\text { Services }\end{array}$ \\
\hline IT & $\checkmark$ & & & \begin{tabular}{l} 
Tourism Services \\
\hline Leisure and tourism
\end{tabular} \\
Infrastructure & $\checkmark$ & & Tourism and Events & Transport Services \\
\hline Advanced Engineering & & $\checkmark$ & Construction / Engineering & Construction \\
\hline Consumer Products & & $\checkmark$ & & Bransport and Logistics \\
\hline Financial Services & & $\checkmark$ & Financial Services & $\begin{array}{l}\text { Business, IT and Professional } \\
\text { Services }\end{array}$ \\
\hline Healthcare Services & & $\checkmark$ & Healthcare Services & Healthcare Services \\
\hline Life Sciences & & $\checkmark$ & Life sciences & Agriculture \\
\hline & & & Creative industries \\
\hline
\end{tabular}

Source: Own construction based on JIC Investment Promotion (2016) and Jordan 2025 (2014)

\footnotetext{
${ }^{20} \mathrm{We}$ presume that this is because employment in major pharmaceutical companies in Jordan is less focused on
} manufacturing and product development and more on business services and logistics. 


\section{Prioritization of Diversification Opportunities}

\section{a. General Considerations}

The process described above aims to identify nearby industries that can leverage the knowhow already in place in Jordan, and that are relatively complex and strategically positioned enough to lead the way to other, more complex industries. In other words, these strategic industries, and the broader export themes into which they are grouped, prioritize opportunities-based complexity measures of their viability and attractiveness. It is up to policymakers to determine if and how to organize state resources to support growth across these export themes. For industries along the extensive margin the Government of Jordan may choose to target investment promotion efforts focusing on absent industries that require capabilities similar to those already present in the country. For industries along the intensive margin, there is often much scope for cooperation between the public and private sectors to identify and resolve sector-specific bottlenecks in order to improve growth in these industries. The identification of export themes can help governments make the most out of their own limited capabilities and resources.

As the Government of Jordan pursues these export themes, it may want to leverage more indicators of viability and attractiveness not explicitly captured by Economic Complexity indicators, in order to further prioritize and focus its efforts within the eight export themes. For example, the Government of Jordan may find industries more attractive if they demand relatively more youth or female labor, since unemployment rates for these segments of the population are very high. Stakeholders may also identify additional factors that affect the viability of industries, such as vulnerability to border closures and water intensity. The export themes outlined in the previous section are therefore more of a starting point for iterative prioritization efforts by the Government of Jordan with other stakeholders.

This section outlines a roadmap for a prioritization exercise within the Jordanian context. In addition to the complexity measures already incorporated, it considers other relevant viability and attractiveness factors. The objective is to suggest a guide for policymakers regarding the type of elements to be evaluated, and how to weigh them to sequence efforts. The factors considered here are specific to the Jordanian context, as the scheme attempts to exploit the country's competitive advantages to the fullest and to avoid, whenever possible, the most binding constraints it faces.

\section{b. Viability and Attractiveness Factors}

Diversification opportunities could be further prioritized according to indicators of viability and attractiveness. As an example, we chose five viability factors and five attractiveness factors to illustrate the process of further targeting strategic industries. Measuring these factors is not always straightforward. In many cases, we use global data or data from the U.S. economy in particular to 
provide industry-level measurements. ${ }^{21}$ The reason for this is that the U.S. has accessible and reliable databases and that its economy reflects industry patterns within an advanced productive structure similar to what Jordan would hope to eventually develop.

The viability factors employed are the following:

- Current Presence in Jordan: The higher the intensity of an industry in a country, the greater the likelihood that the challenges it faces will be manageable. Likewise, the larger the industry, the more local actors there will be with deep knowledge of the challenges facing the sector who could jointly address sector-specific constraints. The level of an industry's presence in Jordan can be approximated through the existing RCA measure that stems from the country's complexity analysis already performed. For industries with an RCA well above one, government actions can be exclusively focused on helping existing actors thrive. For industries with an RCA below one but well above zero, investment promotion efforts may be needed, but there will also be existing actors whose struggles can reveal key issues that must be addressed in order for Jordan to be competitive in that industry.

- Current Presence in Peer Countries ${ }^{22}$ : If an industry is successfully developed in similar environments, then it should be relatively easier for Jordan to develop it as well. A high level of presence in peer countries does not guarantee the industry's success in Jordan, but it is a useful signal that Jordan may be especially poised to succeed in that industry. The average RCA across a group of peer countries is used to measure this factor.

- Water Intensity: Promotion efforts should avoid (at least initially) sectors that are intensive in the factors that represent binding constraints for business activities in Jordan. The growth diagnostic analysis carried out by the Growth Lab identified water scarcity as one of the country's main competitive disadvantages (Hausmann et al. 2019). Therefore, industries that are not intensive in water could be prioritized. To measure this factor, we use the percentage of input costs that are spent on water in the industry in the United States, based on U.S. InputOutput tables.

- Electricity Intensity: The growth diagnostic analysis also identified the high cost of electricity as one of the most relevant constraints to growth in Jordan (Hausmann et al. 2019). Therefore, industries that are not intensive in electricity should be prioritized. In the same way as water intensity, this factor is calculated as the percentage of input costs spent on electricity, again using data from U.S. Input-Output tables.

- Ability to Access Inputs: A crucial element for the development of any productive activity is the ability to access the raw and intermediate material inputs it requires. To measure this variable, we estimate the number of inputs (i) intensively required by the industry in question,

\footnotetext{
${ }^{21}$ Specifically: dependency on water and electricity, ability to access intermediate inputs, and ability to incorporate high-skill and female labor.

${ }^{22}$ Egypt, Israel, Lebanon, Morocco, Tunisia and Turkey were selected as comparators for the purposes of this analysis.
} 
and (ii) those that are currently missing or not accessible in the country. The methodology employed to perform these estimations is explained in detail in Annex 5. Estimates assume that if other activities that demand the same inputs have a significant presence in Jordan, then it is likely that the industry in question will also be able to easily access these inputs, making its development more viable.

The attractiveness factors employed are the following:

- Ability to Incorporate High-Skilled Labor: As stated above, diversification efforts should attempt to exploit the country's competitive advantages to the fullest. Jordan's endowment of high-skilled human capital (Hausmann et al. 2019) is one of its biggest competitive advantages, especially considering the relative wages paid to skilled professionals in Jordan versus elsewhere in the Gulf. Accordingly, we prioritize industries that tend to employ a higher proportion of educated individuals. This factor is measured by the percentage of the jobs in the industry that are filled by high-skilled workers (defined as those who have more than a high school degree, and calculated using data from the U.S. Bureau of Labor Statistics (BLS)).

- Ability to Incorporate Female Labor: As the Jordanian labor force has become more highly educated, the long-term increase in female education levels has been particularly noteworthy (Hausmann et al. 2019), and this pool of underutilized labor reflects another competitive advantage. Currently, the supply of female labor is largely wasted, as high-skilled women face unemployment rates that are between two and three times higher than those faced by men with equivalent education levels, while low-skilled women barely participate in the labor force at all (Kasoolu et al. 2019). If diversification opportunities employ more women, they could serve as an engine for growth and inclusion, and drive a positive shift in hiring practices across the private sector. This factor is represented by the share of jobs held by women in the United States, again measured using BLS data.

- Export Propensity: For the reasons already noted above, Jordan's growth strategy must be driven by exports (Hausmann et al. 2019). If an industry is more prone to be organized around exporting firms, then it is more likely to contribute to strengthening the country's export profile. To measure this factor, the methodology considers the percentage of worldwide employment concentrated in firms that report exporting activity, based $\mathrm{n}$ information from the D\&B database.

- Ability to Attract Foreign Direct Investment Globally: Foreign Direct Investment (FDI) can have multiple benefits, including the strengthening of a country's knowledge base. This factor is measured as the total value of worldwide FDI capital expenditure over a recent period (20032015). For the purposes of constructing this indicator, information from fDi Markets is used. ${ }^{23}$ The methodology employed to perform this estimation is explained in detail in Annex 6.

\footnotetext{
${ }^{23}$ Although this information is available for a classification system different from the one used elsewhere in this analysis (SIC) and is available at a less granular aggregation level, we developed a process that allows us to match FDI flows to the industries of interest. The methodology is explained in detail in Annex 5.
} 
- Ability to Attract Regional Foreign Direct Investment: Industries that have attracted investments in the Middle East and North Africa are further prioritized. We calculate this factor using fDi Markets data but restrict the dataset to foreign investment targeted to the region ${ }^{24}$.

\section{c. Prioritization Scheme}

After evaluating the performance of the different diversification opportunities across the factors described above, it is possible to aggregate this information into a single score in order to assess their general viability and attractiveness. For this purpose, the estimated values must first be normalized, which is done according to the following formula:

$$
N V_{i j}=5+2 *\left[\frac{V_{i j}-\operatorname{mean}_{j}\left(V_{i j}\right)}{s d_{j}\left(V_{i j}\right)}\right]
$$

where $N V_{i j}$ is the (normalized) value of industry $i$ in factor $j$, and $\operatorname{mean}_{j}\left(V_{i j}\right)$ and $s d_{j}\left(V_{i j}\right)$ are the mean and standard deviation, respectively, of all values for factor $\mathrm{j}$. Normalized values that turn out to be less than 0 and greater than 10 are adjusted upward or downward until these limit values are reached. Consequently, the maximum normalized value for any factor is 10 , the minimum is 0 and the average is close to $5 .{ }^{25}$ The similarity of their distribution enables the comparison and aggregation of the normalized values, despite the differences in terms of their levels and any existence of outliers of the original values.

This normalization also facilitates the visualization of the factors that improve and worsen the viability and attractiveness of the different opportunities for diversification. As an example, Figure 14 and Figure 15 show the performance of the Engineering Services industry in the different viability and attractiveness factors, respectively. According to Figure 14, we can conclude that the industry is close to average across almost all viability factors, with the exception of missing inputs, which potentially reflects a viability risk. Meanwhile, Figure 15 highlights that the greatest driver of its attractiveness is its ability to employ high-skilled workers, but that this is somewhat offset by its relatively low capacity to hire women.

24 The reference region was defined as countries in the Middle East and North Africa, with the addition of Turkey.

${ }^{25}$ It is exactly 5 if no upward or downward adjustments are necessary. 
Figure 14: Viability Factors Performance, Normalized Values - Engineering Services

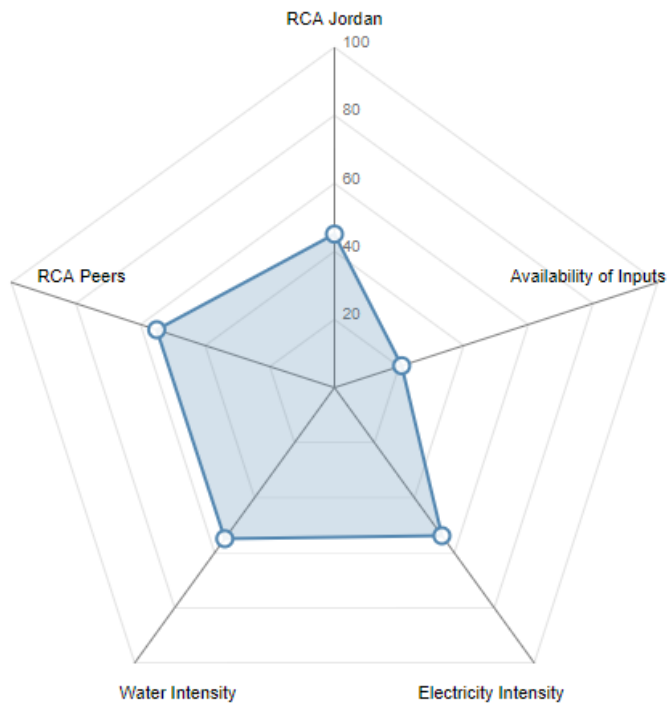

Source: Own construction based on Dun \& Bradstreet and US Input-Output Table

Figure 15: Attractiveness Factors Performance, Normalized Value - Engineering Services

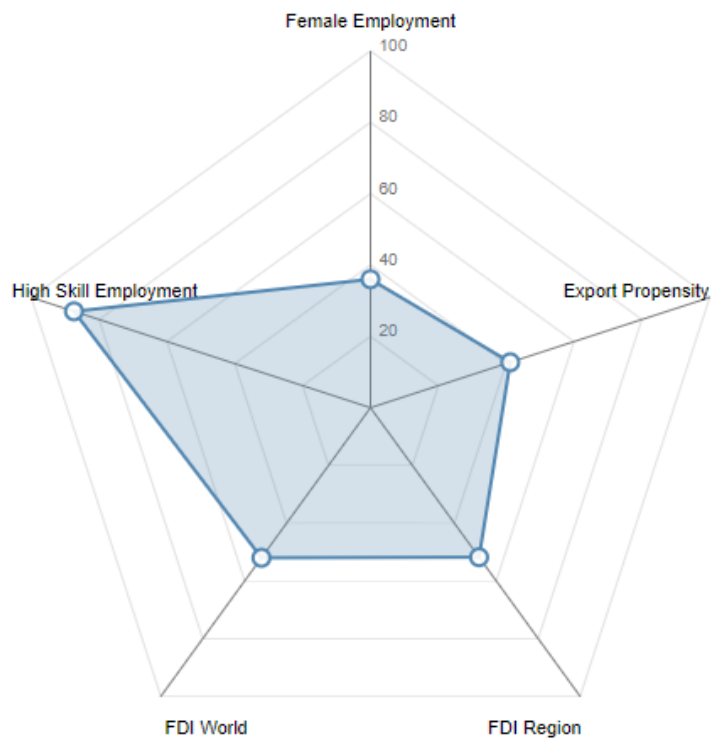

Source: Own construction based on Dun \& Bradstreet, US BLS and fDi Markets 
The normalization of values allows for the calculation of total viability and attractiveness scores based on the sum of the normalized values across factors. We consider an industry to be "highly viable" if its total viability score is greater than the median for all the diversification opportunities, and as "highly attractive" if the total attractiveness score is greater than the median of all diversification opportunities. Although we calculate total scores for diversification opportunities on both the extensive and intensive margins, we consider all intensive margin opportunities to be "highly viable," regardless of their total viability scores. We do this because the high RCA value reflects the fact that these industries have survived in the country despite any viability weaknesses of the explicit factors.

\section{d. Using the Prioritization Scheme}

Based on these total viability and attractiveness scores, government stakeholders can prioritize their use of scarce resources. One possible way of operationalizing this prioritization scheme would be to group industry opportunities into phases is as follows:

- Phase 0: Industries on the intensive margin that are "highly attractive."

- Phase 1: Industries on the extensive margin that are "highly viable" and "highly attractive."

- Phase 2: Industries on the intensive margin that are not "highly attractive" AND industries on the extensive margin and either not "highly viable" or not "highly attractive" (but not both).

- Phase 3: Industries on the extensive margin that are neither "highly viable" nor "highly attractive."

Figure 16 shows how industries on the extensive margin are distributed across these different phases. Although both phase 0 and phase 1 industries are highly viable and highly attractive, the scheme prioritizes those belonging to the intensive margin, assigning them to an earlier phase. While these industries may face complex challenges, they have the advantage of already having a significant number of firms in the country, with which authorities can collaborate to more effectively identify and address industry-specific constraints. Placing these industries in phase 0 reflects that few obstacles stand in the way of expanding government efforts today, whereas even the most promising extensive margin opportunities (in phase 1) will require attracting new domestic or foreign investors.

Figure 17 displays the position of all the strategic industries on a Prioritization Phases map and highlights the position of Engineering Services as an example. With an RCA lower than 1, the industry does not have a revealed comparative advantage in the country, while its above median attractiveness and below median viability lead to a Phase 2 categorization. 
Figure 16: Prioritization Phases of Diversification Opportunities

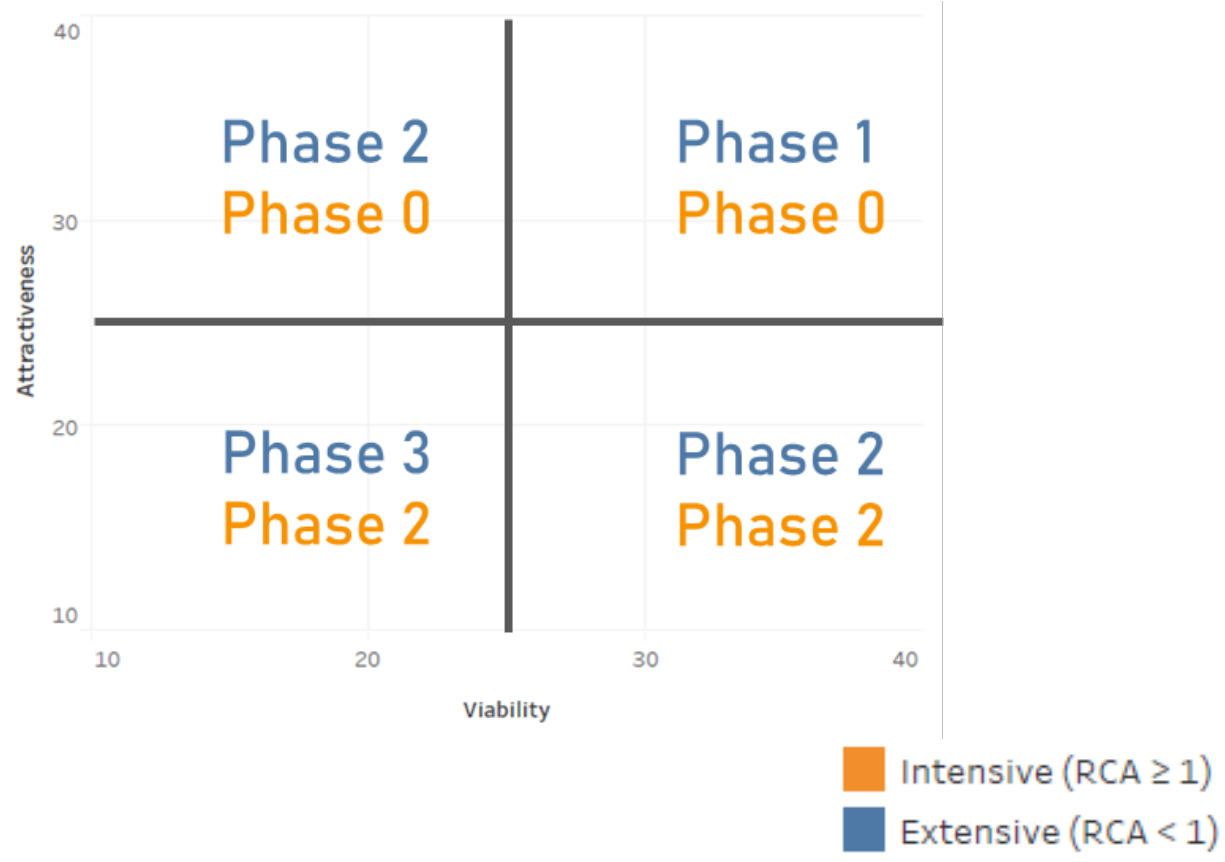

Source: Own construction

Figure 17: Prioritization Phases of Diversification Opportunities - Engineering Services
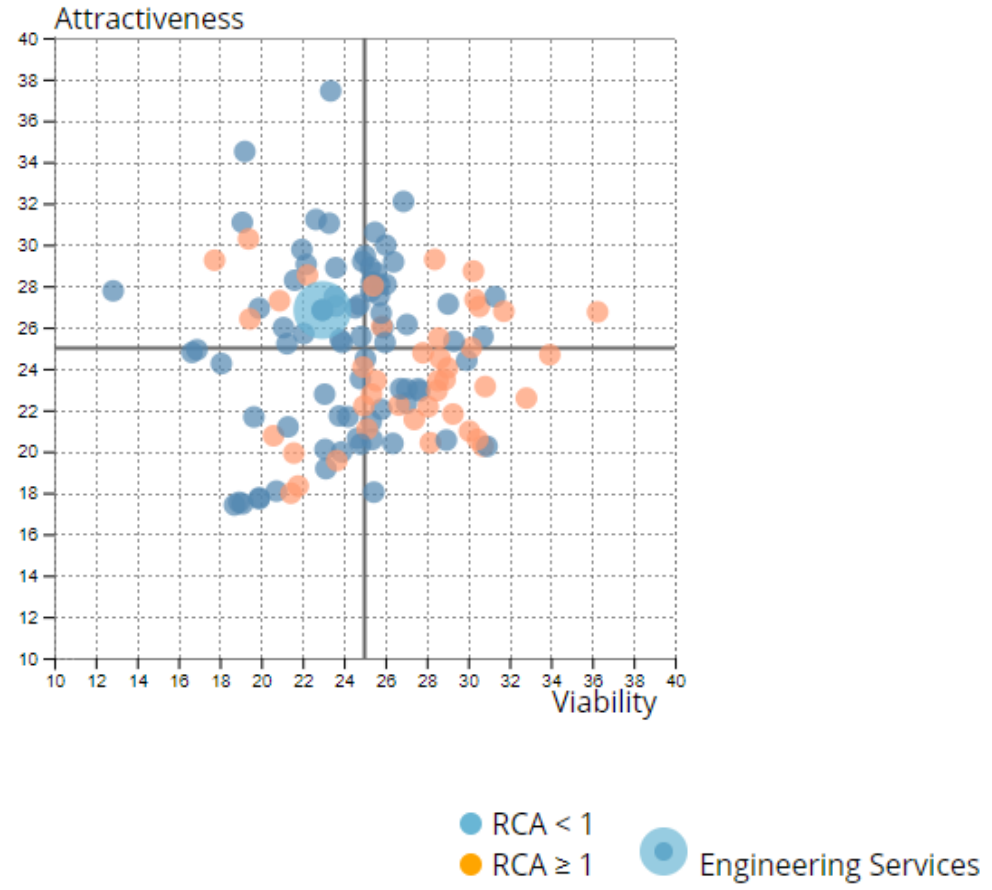

Sources: Own construction based on Dun \& Bradstreet, U.S. Input-Output tables, U.S. BLS, and fDi Markets 
Finally, it is possible to further aggregate this information and consolidate it at the theme and subtheme levels, in order to assess which of them will concentrate the greatest proportion of industries assigned to the earliest phases. This is an important step, since it is more efficient and effective to implement export promotion efforts and attract investments at the theme or sector level, than at the individual industry level. Figure 18 shows the total number of Phase 0 and 1 industries by theme and sub-theme.

Once the focus of opportunities is restricted to Phase 0 and Phase 1, themes and sub-themes that represent more than $10 \%$ of the industries in these phases could be prioritized. When a sub-theme, by itself, represents more than $10 \%$ of industries in Phase 0 and Phase 1 (or when it represents more than $8 \%$, but industries in Phase 0 and Phase 1 represent more than $75 \%$ of the subtheme), it is recommendable to work at the sub-theme level. Otherwise, working at the theme level is advisable.

As a result of this process, themes such as Tourism and Creative Sectors, and sub-themes such as Foodstuffs (Plant-derived products), Legal, Finance and Insurance Services, and Engineering, Accounting and Research would emerge as initial target sectors. This is, of course, just one way of operationalizing the prioritization process. Ultimately, sector prioritization should arise not only from analytical work, but also from a dynamic process carried out jointly by the public and private sectors. 
Figure 18: Industries by Prioritization Phases

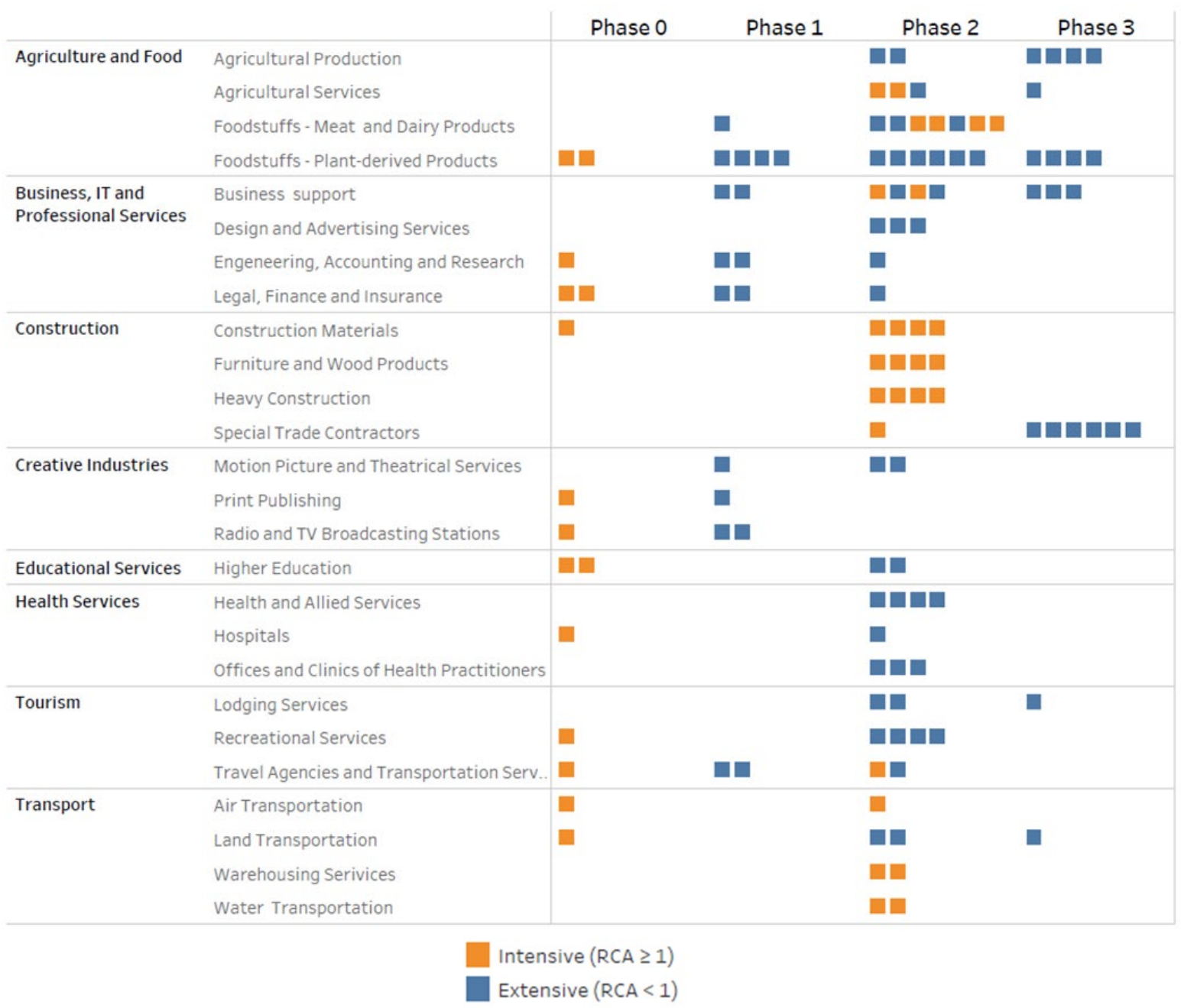

Sources: Own construction based on Dun \& Bradstreet, U.S. Input-Output tables, U.S. BLS, and fDi Markets 


\section{Conclusions}

This paper has summarized an analysis performed by the Growth Lab using Economic Complexity theory in Jordan, one of several components of the Lab's overall research on Jordanian growth strategy carried out in collaboration with the Government of Jordan. The paper charts the development of a new set of complexity measures and an Industry Space that is inclusive of services, and proceeds to apply these tools to identify diversification opportunities for Jordan. The paper further develops a prioritization scheme that the government and other stakeholders can use to help operationalize efforts toward realizing strategic diversification opportunities.

As a result of regional trade and market shocks, increasing prices of utilities, and a long-term shift in Jordan's human capital advantages, Jordan has lost competitiveness in manufactured and agricultural exports over the last two decades. An acceleration of economic growth, an expansion of job opportunities and the promotion of macroeconomic stability in Jordan in the short-tomedium term will depend on the country's ability to expand and diversify its export base to better match the country's factor endowments and comparative advantages. Jordan's current comparative advantages present clear opportunities for more rapid development of high-skill tradable services that serve the region and beyond, as well as narrower opportunities in certain manufactured and agricultural goods. In the longer-term, Jordan must also address major constraints to manufacturing and agriculture on the whole, specifically by expanding water availability and achieving system-wide reductions in the cost of electricity.

After applying newly developed complexity measures and Industry Space analysis, the following strategic export themes for Jordan emerge: (1) Business, IT and Professional Services, (2) Education Services, (3) Healthcare Services, (4) Creative Industries, (5) Tourism, (6) Transportation and Logistics, (7) Construction Materials and Services, and (8) Agriculture and Food Processing. Each of these export themes includes a number of specific industries, which either already have a strong presence in Jordan and could continue to support export and wage growth (the intensive margin) or would be likely to succeed in Jordan given their relatedness to existing capabilities and knowhow (the extensive margin).

The strategic opportunities that emerged from complexity analysis show a striking similarity on the export theme-level to several past strategic exercises that employed different methodologies. Creative industries and some specific opportunities in agriculture and food processing are two areas of great opportunity that show up in our work and have not been mentioned in previous strategic documents, while the complexity analysis suggests fewer opportunities in chemicals. For the rest of the themes, our work provides an added level of specificity within themes to help the Government of Jordan focus its limited state capacity and efforts. Given administrative and budgetary challenges in implementing past strategies, this analysis proceeded to introduce a prioritization scheme that the government and other stakeholders could use or further adapt in order to act on these opportunities. 
Jordan's ability to achieve sustainable and inclusive growth will depend on its ability to capitalize on opportunities on both the intensive and extensive margins. This cannot be a passive process. Rather, it requires government ownership of strategies, openness to iteration and experimentation in their implementation, and active leadership from the highest level of government to fully coordinate efforts and drive change. For opportunities on the intensive margin, it is crucial that the Government of Jordan work jointly with the private sector, in order to understand and iteratively solve industry-specific constraints. Without improved public-public and public-private coordination, solvable problems will linger, keeping promising industries small and costing the country many good jobs. One example of this is Jordan's historically restrictive immigration policies for high-skilled labor, which has constrained the full emergence of many high-skill tradable industries. For opportunities on the extensive margin, the Government of Jordan must treat targeted investment promotion and facilitation of foreign direct investment as a national priority, scaling efforts to address bottlenecks in the system. Attracting and facilitating FDI is also an area where donor support and collaboration can be powerful, as donors can bolster government efforts in reaching and coordinating with companies in their countries and regions.

Beyond the context of Jordan, further research is needed to deepen understanding of the Industry Space, in particular, its capacity to explain and inform future growth and the appearance and disappearance of specific industries over time. Further applications of the Industry Space and service-inclusive complexity measures to other country contexts will also serve to improve the applicability of these tools. 


\section{References}

Balassa, Bela. 1964. “The Purchasing-Power Parity Doctrine: A Reappraisal.” Journal of Political Economy 72 6: 584-596.

Coscia, Michele, and Frank Neffke. 2017. "Network Backboning with Noisy Data." In 2017 IEEE 33rd International Conference on Data Engineering (ICDE), 425-436. IEEE.

Hausmann, Ricardo, Jose Ramon Morales Arilla, and Miguel Angel Santos. 2017. "Panama beyond the Canal: Using Technological Proximities to Identify Opportunities for Productive Diversification," CID Working Paper 324.

Hausmann, Ricardo, César A. Hidalgo, Sebastián Bustos, Michele Coscia, Alexander Simoes, and Muhammed A. Yildirim. 2014. The Atlas of Economic Complexity. MIT Press.

Hausmann, Ricardo, and Bailey Klinger. 2006. "Structural Transformation and Patterns of Comparative Advantage in the Product Space." Harvard Center for International Development, Faculty Working Paper Series, No. 128.

Hausmann, Ricardo, Tim O’Brien, Miguel Angel Santos, Ana Grisanti, and Jorge Tapia. 2019. "Jordan: The Elements of a Growth Strategy." Harvard Center for International Development, Faculty Working Paper Series, No. 346.

Kasoolu, Semiray, Ricardo Hausmann, Tim O'Brien, and Miguel Angel Santos. 2019. "Female Labor in Jordan: A Systematic Approach to the Exclusion Puzzle.” Harvard Center for International Development, Faculty Working Paper Series, No. 346. 


\section{Annex 1: Export Themes and Industries, Jordan}

\begin{tabular}{|c|c|c|c|}
\hline Theme & Subtheme & Intensive Margin & Extensive Margin \\
\hline \multirow[t]{4}{*}{$\begin{array}{l}\text { Agriculture } \\
\text { and Food }\end{array}$} & $\begin{array}{l}\text { Agricultural } \\
\text { Production }\end{array}$ & & $\begin{array}{l}\text { Vegetables and Melons, Sheep and Goats, Dairy Farms, } \\
\text { Chicken Eggs, Poultry and Eggs, Not Elsewhere Classified, } \\
\text { General Farms, Primarily Livestock and Animal Specialties }\end{array}$ \\
\hline & $\begin{array}{l}\text { Agricultural } \\
\text { Services }\end{array}$ & $\begin{array}{l}\text { Crop Harvesting, Primarily by Machine, } \\
\text { Livestock Services, Except Veterinary }\end{array}$ & $\begin{array}{l}\text { Crop Planting, Cultivating, and Protecting, Veterinary } \\
\text { Services for Livestock }\end{array}$ \\
\hline & $\begin{array}{l}\text { Foodstuffs - } \\
\text { Meat and Dairy } \\
\text { Products }\end{array}$ & $\begin{array}{l}\text { Meat Packing Plants, Sausages and Other } \\
\text { Prepared Meat Products, Poultry } \\
\text { Slaughtering and Processing, Ice Cream } \\
\text { and Frozen Desserts }\end{array}$ & $\begin{array}{l}\text { Creamery Butter, Natural, Processed, and Imitation Cheese, } \\
\text { Frozen Specialties, Not Elsewhere Classified, Prepared } \\
\text { Fresh or Frozen Fish and Seafoods }\end{array}$ \\
\hline & $\begin{array}{l}\text { Foodstuffs - } \\
\text { Plant-derived } \\
\text { Products }\end{array}$ & $\begin{array}{l}\text { Dried and Dehydrated Fruits, Vegetables, } \\
\text { and Soup Mixes, Chocolate and Cocoa } \\
\text { Products }\end{array}$ & $\begin{array}{l}\text { Flour and Other Grain Mill Products, Cereal Breakfast } \\
\text { Foods, Rice Milling, Prepared Flour Mixes and Doughs, } \\
\text { Bread and Other Bakery Products, Except Cookies and } \\
\text { Crackers, Frozen Bakery Products, Except Bread, Cane } \\
\text { Sugar, Except Refining, Cane Sugar Refining, Beet Sugar, } \\
\text { Salted and Roasted Nuts and Seeds, Cottonseed Oil Mills, } \\
\text { Soybean Oil Mills, Flavoring Extracts and Flavoring } \\
\text { Syrups, Not Elsewhere Classified, Manufactured Ice }\end{array}$ \\
\hline \multirow[t]{4}{*}{$\begin{array}{r}\text { Business, IT } \\
\text { and } \\
\text { Professional } \\
\text { Services }\end{array}$} & $\begin{array}{l}\text { Business } \\
\text { support }\end{array}$ & $\begin{array}{l}\text { Commercial Printing, Not Elsewhere } \\
\text { Classified, Manifold Business Forms }\end{array}$ & $\begin{array}{l}\text { Building Cleaning and Maintenance Services, Not } \\
\text { Elsewhere, Detective, Guard, and Armored Car Services, } \\
\text { Security Systems Services, Facilities Support Management } \\
\text { Services, Equipment Rental and Leasing, Not Elsewhere } \\
\text { Classified, Employment Agencies, Help Supply Services }\end{array}$ \\
\hline & $\begin{array}{l}\text { Design and } \\
\text { Advertising } \\
\text { Services }\end{array}$ & & $\begin{array}{l}\text { Advertising Agencies, Commercial Photography, } \\
\text { Commercial Art and Graphic Design }\end{array}$ \\
\hline & $\begin{array}{l}\text { Engineering, } \\
\text { Accounting } \\
\text { and Research }\end{array}$ & $\begin{array}{l}\text { Commercial Economic, Sociological, and } \\
\text { Educational Research }\end{array}$ & $\begin{array}{l}\text { Engineering Services, Accounting, Auditing, and } \\
\text { Bookkeeping Services, Management Consulting Services }\end{array}$ \\
\hline & $\begin{array}{l}\text { Legal, Finance } \\
\text { and Insurance }\end{array}$ & $\begin{array}{l}\text { Insurance Carriers, Not Elsewhere } \\
\text { Classified, Credit Reporting Services }\end{array}$ & $\begin{array}{l}\text { Insurance Agents, Brokers, and Service, Offices of Holding } \\
\text { Companies, Not Elsewhere Classified, Legal Services }\end{array}$ \\
\hline \multirow[t]{4}{*}{ Construction } & $\begin{array}{l}\text { Construction } \\
\text { Materials }\end{array}$ & $\begin{array}{l}\text { Flat Glass, Ready-Mixed Concrete, } \\
\text { Mineral Wool, Cold-Rolled Steel Sheet, } \\
\text { Strip, and Bars, Miscellaneous Structural } \\
\text { Metal Work }\end{array}$ & \\
\hline & $\begin{array}{l}\text { Furniture and } \\
\text { Wood Products }\end{array}$ & $\begin{array}{l}\text { Wood Kitchen Cabinets, Prefabricated } \\
\text { Wood Buildings and Components, Wood } \\
\text { Office Furniture, Public Building and } \\
\text { Related Furniture }\end{array}$ & \\
\hline & $\begin{array}{l}\text { Heavy } \\
\text { Construction }\end{array}$ & $\begin{array}{l}\text { Highway and Street Construction, Except } \\
\text { Elevated Highways, Water, Sewer, } \\
\text { Pipeline, and Communications and Power } \\
\text { Line Construction, Heavy Construction, } \\
\text { Not Elsewhere Classified, Elevators and } \\
\text { Moving Stairways }\end{array}$ & \\
\hline & $\begin{array}{l}\text { Special Trade } \\
\text { Contractors }\end{array}$ & $\begin{array}{l}\text { Special Trade Contractors, Not Elsewhere } \\
\text { Classified }\end{array}$ & $\begin{array}{l}\text { Plumbing, Heating and Air-Conditioning, Painting and } \\
\text { Paper Hanging, Electrical Work, Plastering, Drywall, } \\
\text { Acoustical, and Insulation Work, Carpentry Work, Roofing, } \\
\text { Siding, and Sheet Metal Work }\end{array}$ \\
\hline \multirow[t]{3}{*}{$\begin{array}{l}\text { Creative } \\
\text { Industries }\end{array}$} & $\begin{array}{l}\text { Motion Picture } \\
\text { and Theatrical } \\
\text { Services }\end{array}$ & & $\begin{array}{l}\text { Services Allied to Motion Picture Production, Motion } \\
\text { Picture and Video Tape Production, Theatrical Producers } \\
\text { (Except Motion Picture) and Miscellaneous Theatrical } \\
\text { Services }\end{array}$ \\
\hline & $\begin{array}{l}\text { Print } \\
\text { Publishing }\end{array}$ & $\begin{array}{l}\text { Newspapers: Publishing, or Publishing } \\
\text { and Printing }\end{array}$ & Periodicals: Publishing, or Publishing and Printing \\
\hline & $\begin{array}{l}\text { Radio and TV } \\
\text { Broadcasting } \\
\text { Stations }\end{array}$ & Radio Broadcasting Stations & $\begin{array}{l}\text { Television Broadcasting Stations, Radio, Television, and } \\
\text { Publishers' Advertising Representatives }\end{array}$ \\
\hline $\begin{array}{r}\text { Educational } \\
\text { Services }\end{array}$ & $\begin{array}{l}\text { Higher } \\
\text { Education }\end{array}$ & $\begin{array}{l}\text { Colleges, Universities, and Professional } \\
\text { Schools, Schools and Educational } \\
\text { Services, Not Elsewhere Classified }\end{array}$ & $\begin{array}{l}\text { Junior Colleges and Technical Institutes, Vocational } \\
\text { Schools, Not Elsewhere Classified }\end{array}$ \\
\hline
\end{tabular}




\begin{tabular}{|c|c|c|c|}
\hline \multirow[t]{3}{*}{$\begin{array}{r}\text { Health } \\
\text { Services }\end{array}$} & \multicolumn{2}{|l|}{$\begin{array}{l}\text { Health and } \\
\text { Allied Services }\end{array}$} & $\begin{array}{l}\text { Hospital and Medical Service Plans, Medical Laboratories, } \\
\text { Home Health Care Services, Health and Allied Services, } \\
\text { Not Elsewhere Classified }\end{array}$ \\
\hline & Hospitals & Specialty Hospitals, Except Psychiatric & General Medical and Surgical Hospitals \\
\hline & $\begin{array}{l}\text { Offices and } \\
\text { Clinics of } \\
\text { Health } \\
\text { Practitioners }\end{array}$ & & $\begin{array}{l}\text { Offices and Clinics of Dentists, Offices and Clinics of } \\
\text { Health Practitioners, Not Elsewhere Classified, Specialty } \\
\text { Outpatient Facilities, Not Elsewhere Classified }\end{array}$ \\
\hline \multirow[t]{3}{*}{ Tourism } & $\begin{array}{l}\text { Lodging } \\
\text { Services }\end{array}$ & & $\begin{array}{l}\text { Hotels and Motels, Rooming and Boarding Houses, } \\
\text { Organization Hotels and Lodging Houses, on Membership } \\
\text { Basis }\end{array}$ \\
\hline & $\begin{array}{l}\text { Recreational } \\
\text { Services }\end{array}$ & $\begin{array}{l}\text { Amusement and Recreation Services, Not } \\
\text { Elsewhere Classified }\end{array}$ & $\begin{array}{l}\text { Sporting and Recreational Camps, Amusement Parks, } \\
\text { Museums and Art Galleries, Arboreta and Botanical or } \\
\text { Zoological Gardens }\end{array}$ \\
\hline & $\begin{array}{l}\text { Travel } \\
\text { Agencies and } \\
\text { Transportation } \\
\text { Services }\end{array}$ & Passenger Car Rental, Travel Agencies & $\begin{array}{l}\text { Water Transportation of Passengers, Not Elsewhere } \\
\text { Classified, Arrangement of Passenger Transportation, Not } \\
\text { Elsewhere Classified, Tour Operators }\end{array}$ \\
\hline \multirow[t]{4}{*}{ Transport } & $\begin{array}{l}\text { Air } \\
\text { Transportation }\end{array}$ & $\begin{array}{l}\text { Air Transportation, Nonscheduled, } \\
\text { Airports, Flying Fields, and Airport } \\
\text { Terminal Services }\end{array}$ & \\
\hline & $\begin{array}{l}\text { Land } \\
\text { Transportation }\end{array}$ & Truck Trailers & $\begin{array}{l}\text { Trucking, Except Local, Courier Services, Except by Air, } \\
\text { Rental of Railroad Cars }\end{array}$ \\
\hline & $\begin{array}{l}\text { Warehousing } \\
\text { Services }\end{array}$ & $\begin{array}{l}\text { Refrigerated Warehousing and Storage, } \\
\text { Packing and Crating }\end{array}$ & \\
\hline & $\begin{array}{l}\text { Water } \\
\text { Transportation }\end{array}$ & $\begin{array}{l}\text { Marine Cargo Handling, Water } \\
\text { Transportation Services, Not Elsewhere } \\
\text { Classified }\end{array}$ & \\
\hline
\end{tabular}

Source: Own construction based on Dun \& Bradstreet and fDi Markets 


\section{Annex 2: Description of Export Subthemes}

\begin{tabular}{|c|c|c|}
\hline Theme & Subtheme & Description \\
\hline \multirow[t]{4}{*}{$\begin{array}{r}\text { Agriculture and } \\
\text { Food }\end{array}$} & $\begin{array}{l}\text { Agricultural } \\
\text { Production }\end{array}$ & $\begin{array}{l}\text { Establishments primarily engaged in the production of crops, plants, vines, and trees } \\
\text { (excluding forestry operations), and primarily engaged in the keeping, grazing, or feeding of } \\
\text { livestock for the sale of livestock or livestock products (e.g., farms, orchards, greenhouses, } \\
\text { nurseries, ranches, dairies, feedlots, egg production facilities, broiler facilities, poultry } \\
\text { hatcheries, apiaries). }\end{array}$ \\
\hline & $\begin{array}{l}\text { Agricultural } \\
\text { Services }\end{array}$ & $\begin{array}{l}\text { Establishments primarily engaged in performing soil preparation services, crop services, } \\
\text { veterinary services, other animal services, farm labor and management services, and } \\
\text { landscape and horticultural services, for others on a contract or fee basis. }\end{array}$ \\
\hline & $\begin{array}{l}\text { Foodstuffs - Meat } \\
\text { and Dairy Products }\end{array}$ & $\begin{array}{l}\text { Establishments manufacturing or processing foods and beverages with mainly animal origin } \\
\text { for human consumption (e.g., processed meats and processed products derived from milk). }\end{array}$ \\
\hline & $\begin{array}{l}\text { Foodstuffs - Plant- } \\
\text { derived Products }\end{array}$ & $\begin{array}{l}\text { Establishments manufacturing or processing foods and beverages with mainly plant-based } \\
\text { origin for human consumption (e.g., grains, cereals, nuts, and all its derivatives at different } \\
\text { processing stages). }\end{array}$ \\
\hline \multirow[t]{5}{*}{$\begin{array}{r}\text { Business, IT and } \\
\text { Professional } \\
\text { Services }\end{array}$} & Business support & $\begin{array}{l}\text { Establishments primarily engaged in performing a range of services in support of the } \\
\text { operations of other establishments or in providing a number of different continuing services, } \\
\text { on a contract or fee basis, within another establishment; includes establishments providing } \\
\text { personnel and monitoring security systems, commercial printing by one or more common } \\
\text { processes, and other building cleaning and maintenance services such as window cleaning, } \\
\text { janitorial service, floor waxing, and office cleaning. }\end{array}$ \\
\hline & Business support & $\begin{array}{l}\text { Establishments primarily engaged in renting or leasing (except finance leasing) equipment } \\
\text { of various types (including electrical and appliances, furniture, and even trucks and } \\
\text { airplanes), an/or providing personnel and employment services, both on a short-term and } \\
\text { long-term basis. }\end{array}$ \\
\hline & $\begin{array}{l}\text { Design and } \\
\text { Advertising } \\
\text { Services }\end{array}$ & $\begin{array}{l}\text { Establishments primarily engaged in rendering various business services with artistic and } \\
\text { designing purposes on a contract or fee basis; includes establishments providing full } \\
\text { advertising services (preparing and placing on media outlets), and general commercial } \\
\text { photography services and/or commercial art or graphic design services for other advertising } \\
\text { agencies, publishers, and other business and industrial users. }\end{array}$ \\
\hline & $\begin{array}{l}\text { Engineering, } \\
\text { Accounting and } \\
\text { Research }\end{array}$ & $\begin{array}{l}\text { Establishments primarily engaged in providing engineering, and surveying services; } \\
\text { accounting, auditing, and bookkeeping services; research, development, and testing } \\
\text { services; and management services. }\end{array}$ \\
\hline & $\begin{array}{l}\text { Legal, Finance and } \\
\text { Insurance }\end{array}$ & $\begin{array}{l}\text { Establishments including carriers of insurance of all types, except health insurance; } \\
\text { investment trusts, investment companies, holding companies, and miscellaneous investment } \\
\text { offices; establishments which are headed by members of the bar and are engaged in offering } \\
\text { legal advice or legal services; and consumer Credit Reporting Agencies. }\end{array}$ \\
\hline \multirow[t]{4}{*}{ Construction } & $\begin{array}{l}\text { Construction } \\
\text { Materials }\end{array}$ & $\begin{array}{l}\text { Establishments engaged in manufacturing products taken principally from stone, clay, sand } \\
\text { and metal, which are generally used as construction materials. Includes establishments that } \\
\text { manufacture flat glass and other glass products; cement; structural clay products; concrete } \\
\text { and gypsum products; cut stone; abrasive and asbestos products; in addition to } \\
\text { establishments engaged in smelting and refining ferrous and nonferrous metals from ore, } \\
\text { pig, or scrap; in rolling, drawing, and alloying metals; and in manufacturing castings and } \\
\text { other basic metal products. }\end{array}$ \\
\hline & $\begin{array}{l}\text { Furniture and } \\
\text { Wood Products }\end{array}$ & $\begin{array}{l}\text { Establishments engaged in cutting timber and pulpwood; merchant sawmills, lath mills, } \\
\text { shingle mills, cooperage stock mills, planning mills, and plywood mills and veneer mills } \\
\text { engaged in producing lumber and wood basic materials; and establishments engaged in } \\
\text { manufacturing finished articles made mainly of wood such as various types of furniture. }\end{array}$ \\
\hline & $\begin{array}{l}\text { Heavy } \\
\text { Construction }\end{array}$ & $\begin{array}{l}\text { General contractors primarily engaged in heavy construction, such as highways and streets, } \\
\text { bridges, sewers, railroads, irrigation projects, and special trade contractors primarily } \\
\text { engaged in activities of a type that are clearly specialized to such heavy construction, } \\
\text { including some activity related to building construction. }\end{array}$ \\
\hline & $\begin{array}{l}\text { Special Trade } \\
\text { Contractors }\end{array}$ & $\begin{array}{l}\text { Special trade contractors who undertake activities of a type that are specialized either to } \\
\text { building construction, or to both building and non-building projects. These activities include } \\
\text { painting (including bridge painting and traffic lane painting), electrical work (including } \\
\text { work on bridges, power lines, and power plants), carpentry work, plumbing, heating, air- } \\
\text { conditioning, roofing, and sheet metal work. }\end{array}$ \\
\hline
\end{tabular}


Creative Industries

Educational
Services
Health Services

Health Services

\begin{tabular}{l|l} 
Services & Hospitals \\
& $\begin{array}{l}\text { Offices and Clinics } \\
\text { of Health } \\
\text { Practitioners }\end{array}$ \\
Tourism & $\begin{array}{l}\text { Lodging Services } \\
\text { To }\end{array}$
\end{tabular}

Tourism Lodging Services

Transport
Motion Picture and Theatrical Services

Print Publishing

Radio and TV

Broadcasting

Stations

Higher Education

Health and Allied

Services

A

Recreational

Services

Travel Agencies and Transportation

Services

Air Transportation

Land

Transportation

Warehousing

Services

Water

Transportation
Establishments producing and distributing motion pictures and other live theatrical production, exhibiting such productions in commercially operated theaters, and furnishing services to the motion picture and theatrical industry; such as casting agencies; booking agencies; scenery, lighting, and other equipment services; and theatrical ticket agencies. Establishments engaged in printing by one or more common processes, such as letterpress; lithography (including offset), gravure, or screen; and those establishments which perform services for the printing trade, such as bookbinding and platemaking. This major group also includes establishments engaged in publishing newspapers, books, and periodicals, regardless of whether or not they do their own printing.

Establishments furnishing point-to-point communications services, whether intended to be received aurally or visually, such as radio and television broadcasting; in addition to establishments providing services allied to the radio and television broadcasting industries, such as advertising services.

Establishments providing academic or technical instruction, past the high school level (e.g. formal four year and two year undergraduate institutions, professional development and training schools, and other schools of more particular instruction)

Establishments primarily engaged in providing health and allied services, including insurance benefits to subscribers in accordance with service plans, providing skilled nursing or medical care in the home, and other allied health services. Also includes establishments such as laboratories primarily engaged in providing professional analytic or diagnostic services to the medical profession.

Establishments primarily engaged in providing general medical and surgical services and other hospital services such as diagnostic services and treatment for specialized categories of patients, except mental.

Establishments of licensed practitioners having the degree of D.M.D. or D.D.S. (or D.D.Sc.) and engaged in the practice of general or specialized dentistry, or licensed and unlicensed practitioners in health fields not easily classified (e.g. acupuncturists, dieticians midwives, etc.). Also includes establishments primarily engaged in outpatient care of a specialized nature

Commercial establishments, known to the public as hotels, motor hotels, motels, or tourist courts, primarily engaged in providing lodging, or lodging and meals, for the general public. Also includes, establishments primarily engaged in renting rooms, with or without board, on a fee basis, and lodging houses and hotels operated by membership organizations for the benefit of their constituents (not open to the general public).

Establishments engaged in providing amusement or entertainment services, which are largely dependent on the tourism industry; includes amusement parks and kiddie parks, sporting and recreational camps, such as boys' and girls' summer activity camps, museums, art galleries and botanical or zoological gardens.

Establishments primarily engaged in furnishing travel information and acting as agents in arranging or operating tours, transportation, rental of cars, and lodging for travelers. Also includes other passenger transportation services largely dependent of the tourism industry, such as short-term car rental and passenger water transportation services.

Establishments engaged in furnishing domestic and foreign transportation by air, particularly nonscheduled, and also those operating airports and flying fields and furnishing terminal services.

Establishments furnishing long-distance trucking, transfer services, or other services related to freight transportation by land, including courier services, and railroad car rental.

Establishments engaged in the storage of farm products, furniture and other household goods, or commercial goods of any nature, and those engaged in the packing and crating of these products thereof.

Establishments engaged in freight transportation on the open seas or inland waters, and establishments furnishing such incidental services as lighterage, towing, and canal operation. 


\section{Annex 3: Viability Factors Performance}

\begin{tabular}{|c|c|c|c|c|c|c|}
\hline Sic4 & Industry Description & $\begin{array}{c}\text { RCA } \\
\text { Jordan }\end{array}$ & $\begin{array}{c}\text { Av. RCA } \\
\text { Peers }\end{array}$ & $\begin{array}{c}\text { Water } \\
\text { Intensity }\end{array}$ & $\begin{array}{c}\text { Electricity } \\
\text { Intensity }\end{array}$ & $\begin{array}{c}\text { Missing } \\
\text { Inputs }\end{array}$ \\
\hline 161 & Vegetables and Melons & 3.88 & 4.88 & 0.00 & 4.97 & 5.91 \\
\hline 214 & Sheep and Goats & 3.95 & 3.25 & 5.25 & 5.73 & 4.95 \\
\hline 241 & Dairy Farms & 3.98 & 4.00 & 5.33 & 5.63 & 4.95 \\
\hline 252 & Chicken Eggs & 3.88 & 6.91 & 5.23 & 6.06 & 4.95 \\
\hline 259 & Poultry and Eggs, Not Elsewhere Classified & 4.10 & 5.04 & 5.23 & 6.06 & 4.95 \\
\hline 291 & General Farms, Primarily Livestock and Animal Specialties & 4.01 & 3.15 & 5.25 & 5.73 & 4.95 \\
\hline 722 & Crop Harvesting, Primarily by Machine & 10.00 & 3.69 & 5.32 & 5.80 & 5.91 \\
\hline 751 & Livestock Services, Except Veterinary & 7.88 & 4.22 & 5.50 & 5.92 & 6.55 \\
\hline 721 & Crop Planting, Cultivating, and Protecting & 3.88 & 3.74 & 5.32 & 5.80 & 5.91 \\
\hline 741 & Veterinary Services for Livestock & 3.88 & 3.42 & 5.66 & 6.01 & 4.32 \\
\hline 2011 & Meat Packing Plants & 7.16 & 3.80 & 5.56 & 5.96 & 6.55 \\
\hline 2013 & Sausages and Other Prepared Meat Products & 6.11 & 6.65 & 5.56 & 5.96 & 6.55 \\
\hline 2015 & Poultry Slaughtering and Processing & 10.00 & 6.78 & 5.19 & 5.42 & 6.55 \\
\hline 2024 & Ice Cream and Frozen Desserts & 8.47 & 7.72 & 5.08 & 5.00 & 6.55 \\
\hline 2021 & Creamery Butter & 4.23 & 5.51 & 5.21 & 5.52 & 6.55 \\
\hline 2022 & Natural, Processed, and Imitation Cheese & 4.11 & 7.89 & 5.55 & 5.84 & 6.55 \\
\hline 2038 & Frozen Specialties, Not Elsewhere Classified & 3.88 & 3.18 & 5.28 & 4.94 & 6.55 \\
\hline 2092 & Prepared Fresh or Frozen Fish and Seafoods & 3.88 & 3.57 & 5.47 & 5.86 & 6.55 \\
\hline 2034 & Dried and Dehydrated Fruits, Vegetables, and Soup Mixes & 6.74 & 7.12 & 5.24 & 4.90 & 6.55 \\
\hline 2066 & Chocolate and Cocoa Products & 10.00 & 8.83 & 5.21 & 5.36 & 6.87 \\
\hline 2041 & Flour and Other Grain Mill Products & 4.73 & 6.76 & 5.49 & 3.74 & 6.87 \\
\hline 2043 & Cereal Breakfast Foods & 3.88 & 4.02 & 5.57 & 5.69 & 6.55 \\
\hline 2044 & Rice Milling & 3.88 & 3.09 & 5.49 & 3.74 & 6.87 \\
\hline 2045 & Prepared Flour Mixes and Doughs & 3.88 & 4.34 & 5.46 & 5.27 & 6.87 \\
\hline 2051 & Bread and Other Bakery Products, Except Cookies and Crackers & 4.28 & 3.97 & 5.25 & 4.75 & 6.55 \\
\hline 2053 & Frozen Bakery Products, Except Bread & 3.88 & 7.23 & 5.25 & 4.75 & 6.55 \\
\hline 2061 & Cane Sugar, Except Refining & 3.88 & 3.97 & 5.21 & 5.36 & 6.87 \\
\hline 2062 & Cane Sugar Refining & 3.88 & 3.59 & 5.21 & 5.36 & 6.87 \\
\hline 2063 & Beet Sugar & 3.88 & 10.00 & 5.21 & 5.36 & 6.87 \\
\hline 2068 & Salted and Roasted Nuts and Seeds & 4.23 & 4.27 & 5.32 & 5.66 & 6.55 \\
\hline 2074 & Cottonseed Oil Mills & 3.88 & 3.43 & 5.55 & 5.92 & 6.55 \\
\hline 2075 & Soybean Oil Mills & 3.88 & 3.15 & 5.55 & 5.92 & 6.55 \\
\hline 2087 & Flavoring Extracts and Flavoring Syrups, Not Elsewhere Classified & 4.25 & 4.23 & 5.21 & 5.64 & 6.55 \\
\hline 2097 & Manufactured Ice & 3.88 & 3.42 & 5.08 & 4.95 & 6.87 \\
\hline 2759 & Commercial Printing, Not Elsewhere Classified & 5.31 & 4.79 & 5.41 & 3.81 & 6.23 \\
\hline 2761 & Manifold Business Forms & 6.71 & 4.49 & 5.41 & 3.81 & 6.23 \\
\hline 7349 & Building Cleaning and Maintenance Services, Not Elsewhere & 4.12 & 4.44 & 5.15 & 5.75 & 4.32 \\
\hline 7381 & Detective, Guard, and Armored Car Services & 4.51 & 5.39 & 5.59 & 5.93 & 4.95 \\
\hline 7382 & Security Systems Services & 4.28 & 8.20 & 5.59 & 5.93 & 4.95 \\
\hline
\end{tabular}




\begin{tabular}{|c|c|c|c|c|c|c|}
\hline 8744 & Facilities Support Management Services & 4.44 & 3.59 & 0.00 & 4.14 & 5.91 \\
\hline 7359 & Equipment Rental and Leasing, Not Elsewhere Classified & 4.24 & 3.85 & 5.26 & 5.55 & 2.40 \\
\hline 7361 & Employment Agencies & 3.92 & 3.20 & 5.64 & 6.17 & 6.87 \\
\hline 7363 & Help Supply Services & 4.02 & 4.59 & 5.65 & 6.23 & 6.55 \\
\hline 7311 & Advertising Agencies & 3.98 & 4.19 & 5.64 & 5.62 & 5.59 \\
\hline 7335 & Commercial Photography & 3.88 & 3.25 & 5.66 & 5.84 & 5.27 \\
\hline 7336 & Commercial Art and Graphic Design & 3.94 & 3.78 & 5.58 & 4.72 & 5.59 \\
\hline 8732 & Commercial Economic, Sociological, and Educational Research & 5.68 & 5.21 & 5.51 & 5.36 & 0.49 \\
\hline 8711 & Engineering Services & 4.51 & 5.50 & 5.49 & 5.38 & 2.08 \\
\hline 8721 & Accounting, Auditing, and Bookkeeping Services & 4.06 & 4.60 & 5.51 & 5.41 & 5.91 \\
\hline 8742 & Management Consulting Services & 4.18 & 3.91 & 5.63 & 6.12 & 6.55 \\
\hline 6399 & Insurance Carriers, Not Elsewhere Classified & 5.67 & 6.02 & 5.68 & 6.34 & 6.55 \\
\hline 7323 & Credit Reporting Services & 5.90 & 6.34 & 4.98 & 5.45 & 5.91 \\
\hline 6411 & Insurance Agents, Brokers, and Service & 4.21 & 4.45 & 5.69 & 6.30 & 6.23 \\
\hline 6719 & Offices of Holding Companies, Not Elsewhere Classified & 4.45 & 6.17 & 5.60 & 2.51 & 4.64 \\
\hline 8111 & Legal Services & 4.00 & 4.09 & 5.55 & 5.84 & 6.55 \\
\hline 3211 & Flat Glass & 5.12 & 4.27 & 4.86 & 0.42 & 6.23 \\
\hline 3273 & Ready-Mixed Concrete & 5.71 & 5.21 & 5.32 & 5.38 & 6.55 \\
\hline 3296 & Mineral Wool & 10.00 & 4.13 & 4.44 & 0.00 & 6.55 \\
\hline 3316 & Cold-Rolled Steel Sheet, Strip, and Bars & 5.34 & 3.20 & 5.40 & 4.75 & 6.23 \\
\hline 3449 & Miscellaneous Structural Metal Work & 5.21 & 5.61 & 5.51 & 5.48 & 5.59 \\
\hline 2434 & Wood Kitchen Cabinets & 7.04 & 4.80 & 5.33 & 4.82 & 6.55 \\
\hline 2452 & Prefabricated Wood Buildings and Components & 6.89 & 4.88 & 5.42 & 4.79 & 3.36 \\
\hline 2521 & Wood Office Furniture & 5.65 & 4.58 & 5.40 & 5.32 & 6.87 \\
\hline 2531 & Public Building and Related Furniture & 4.99 & 5.41 & 5.55 & 5.83 & 6.87 \\
\hline 1611 & Highway and Street Construction, Except Elevated Highways & 5.03 & 7.28 & 5.32 & 5.87 & 0.17 \\
\hline 1623 & Water, Sewer, Pipeline, and Communications and Power Line Construction & 4.89 & 5.54 & 5.32 & 5.87 & 0.17 \\
\hline 1629 & Heavy Construction, Not Elsewhere Classified & 5.10 & 5.13 & 5.32 & 5.87 & 0.17 \\
\hline 3534 & Elevators and Moving Stairways & 5.69 & 7.01 & 5.71 & 6.39 & 0.17 \\
\hline 1799 & Special Trade Contractors, Not Elsewhere Classified & 5.16 & 4.94 & 5.32 & 5.87 & 0.17 \\
\hline 1711 & Plumbing, Heating and Air-Conditioning & 4.26 & 4.29 & 5.32 & 5.87 & 0.17 \\
\hline 1721 & Painting and Paper Hanging & 3.88 & 3.47 & 5.32 & 5.87 & 0.17 \\
\hline 1731 & Electrical Work & 4.66 & 4.72 & 5.32 & 5.87 & 0.17 \\
\hline 1742 & Plastering, Drywall, Acoustical, and Insulation Work & 3.88 & 3.87 & 5.32 & 5.87 & 0.17 \\
\hline 1751 & Carpentry Work & 3.88 & 4.68 & 5.32 & 5.87 & 0.17 \\
\hline 1761 & Roofing, Siding, and Sheet Metal Work & 3.88 & 3.70 & 5.32 & 5.87 & 0.17 \\
\hline 7819 & Services Allied to Motion Picture Production & 4.16 & 3.43 & 5.52 & 5.86 & 5.59 \\
\hline 7812 & Motion Picture and Video Tape Production & 4.26 & 4.16 & 5.64 & 5.70 & 6.23 \\
\hline 7922 & $\begin{array}{l}\text { Theatrical Producers (Except Motion Picture) and Miscellaneous Theatrical } \\
\text { Services }\end{array}$ & 3.90 & 3.82 & 5.51 & 5.68 & 5.91 \\
\hline 2711 & Newspapers: Publishing, or Publishing and Printing & 5.01 & 4.31 & 5.56 & 5.36 & 5.59 \\
\hline 2721 & Periodicals: Publishing, or Publishing and Printing & 3.95 & 4.66 & 5.56 & 5.81 & 5.59 \\
\hline 4832 & Radio Broadcasting Stations & 8.24 & 4.40 & 5.50 & 6.12 & 5.91 \\
\hline
\end{tabular}




\begin{tabular}{|c|c|c|c|c|c|c|}
\hline 4833 & Television Broadcasting Stations & 4.25 & 7.53 & 5.50 & 6.12 & 5.91 \\
\hline 7313 & Radio, Television, and Publishers' Advertising Representatives & 4.46 & 4.40 & 5.64 & 5.62 & 5.59 \\
\hline 8221 & Colleges, Universities, and Professional Schools & 7.07 & 5.25 & 0.00 & 1.43 & 4.00 \\
\hline 8299 & Schools and Educational Services, Not Elsewhere Classified & 5.19 & 3.90 & 5.60 & 6.09 & 4.64 \\
\hline 8222 & Junior Colleges and Technical Institutes & 4.12 & 3.30 & 0.00 & 1.43 & 4.00 \\
\hline 8249 & Vocational Schools, Not Elsewhere Classified & 4.11 & 3.18 & 5.60 & 6.09 & 4.64 \\
\hline 6324 & Hospital and Medical Service Plans & 3.88 & 3.87 & 5.29 & 6.35 & 5.91 \\
\hline 8071 & Medical Laboratories & 4.39 & 3.82 & 5.55 & 5.47 & 4.32 \\
\hline 8082 & Home Health Care Services & 4.03 & 3.26 & 5.52 & 6.03 & 5.91 \\
\hline 8099 & Health and Allied Services, Not Elsewhere Classified & 4.14 & 3.36 & 5.48 & 5.29 & 3.36 \\
\hline 8069 & Specialty Hospitals, Except Psychiatric & 4.94 & 3.57 & 4.94 & 4.18 & 1.76 \\
\hline 8062 & General Medical and Surgical Hospitals & 4.51 & 3.70 & 4.94 & 4.18 & 1.76 \\
\hline 8021 & Offices and Clinics of Dentists & 3.88 & 3.72 & 5.32 & 4.95 & 4.32 \\
\hline 8049 & Offices and Clinics of Health Practitioners, Not Elsewhere Classified & 3.88 & 3.15 & 5.69 & 5.29 & 4.64 \\
\hline 8093 & Specialty Outpatient Facilities, Not Elsewhere Classified & 3.88 & 3.19 & 5.38 & 5.52 & 4.00 \\
\hline 7011 & Hotels and Motels & 4.66 & 5.23 & 3.88 & 1.12 & 4.32 \\
\hline 7021 & Rooming and Boarding Houses & 4.16 & 3.18 & 3.88 & 1.12 & 4.32 \\
\hline 7041 & Organization Hotels and Lodging Houses, on Membership Basis & 4.04 & 7.88 & 3.88 & 1.12 & 4.32 \\
\hline 7999 & Amusement and Recreation Services, Not Elsewhere Classified & 5.41 & 3.76 & 4.60 & 3.93 & 1.76 \\
\hline 7032 & Sporting and Recreational Camps & 3.97 & 3.61 & 3.88 & 1.12 & 4.32 \\
\hline 7996 & Amusement Parks & 3.93 & 3.71 & 4.99 & 2.97 & 4.32 \\
\hline 8412 & Museums and Art Galleries & 4.18 & 3.94 & 5.19 & 3.15 & 5.59 \\
\hline 8422 & Arboreta and Botanical or Zoological Gardens & 3.88 & 3.26 & 5.19 & 3.15 & 5.59 \\
\hline 7514 & Passenger Car Rental & 5.25 & 5.12 & 5.46 & 5.69 & 6.55 \\
\hline 4724 & Travel Agencies & 4.97 & 5.36 & 5.60 & 5.91 & 6.55 \\
\hline 4489 & Water Transportation of Passengers, Not Elsewhere Classified & 3.88 & 7.36 & 5.66 & 6.16 & 3.68 \\
\hline 4729 & Arrangement of Passenger Transportation, Not Elsewhere Classified & 3.99 & 10.00 & 5.63 & 5.82 & 5.27 \\
\hline 4725 & Tour Operators & 4.61 & 6.37 & 5.60 & 5.91 & 6.55 \\
\hline 4522 & Air Transportation, Nonscheduled & 7.03 & 8.54 & 5.63 & 5.89 & 4.64 \\
\hline 4581 & Airports, Flying Fields, and Airport Terminal Services & 7.16 & 8.18 & 5.45 & 5.75 & 2.72 \\
\hline 3715 & Truck Trailers & 5.43 & 8.03 & 5.64 & 5.97 & 5.27 \\
\hline 4213 & Trucking, Except Local & 3.88 & 3.22 & 5.64 & 5.85 & 6.87 \\
\hline 4215 & Courier Services, Except by Air & 4.07 & 3.20 & 5.44 & 5.87 & 6.23 \\
\hline 4741 & Rental of Railroad Cars & 4.21 & 10.00 & 5.61 & 5.83 & 5.27 \\
\hline 4222 & Refrigerated Warehousing and Storage & 4.84 & 4.29 & 5.24 & 0.00 & 6.23 \\
\hline 4783 & Packing and Crating & 5.67 & 8.08 & 5.65 & 5.80 & 5.27 \\
\hline 4491 & Marine Cargo Handling & 6.10 & 5.68 & 5.65 & 5.80 & 5.27 \\
\hline 4499 & Water Transportation Services, Not Elsewhere Classified & 5.01 & 7.52 & 5.62 & 5.78 & 4.95 \\
\hline
\end{tabular}




\section{Annex 4: Attractiveness Factors Performance}

\begin{tabular}{|c|c|c|c|c|c|c|}
\hline Sic4 & Industry Description & $\begin{array}{c}\text { Female } \\
\text { Employment }\end{array}$ & $\begin{array}{c}\text { High Skill } \\
\text { Employment }\end{array}$ & $\begin{array}{c}\text { FDI } \\
\text { World }\end{array}$ & $\begin{array}{c}\text { FDI } \\
\text { Region }\end{array}$ & $\begin{array}{c}\text { Export } \\
\text { Propensity }\end{array}$ \\
\hline 161 & Vegetables and Melons & 3.36 & 3.11 & 4.58 & 4.70 & 5.93 \\
\hline 214 & Sheep and Goats & 3.47 & 3.29 & 4.48 & 4.70 & 3.23 \\
\hline 241 & Dairy Farms & 3.47 & 3.29 & 4.58 & 4.71 & 3.92 \\
\hline 252 & Chicken Eggs & 3.47 & 3.29 & 4.47 & 4.69 & 7.09 \\
\hline 259 & Poultry and Eggs, Not Elsewhere Classified & 3.47 & 3.29 & 4.48 & 4.70 & 4.64 \\
\hline 291 & General Farms, Primarily Livestock and Animal Specialties & 3.47 & 3.29 & 4.54 & 4.70 & 4.09 \\
\hline 722 & Crop Harvesting, Primarily by Machine & 4.22 & 3.37 & 4.47 & 4.69 & 3.50 \\
\hline 751 & Livestock Services, Except Veterinary & 4.62 & 2.54 & 4.46 & 4.69 & 4.66 \\
\hline 721 & Crop Planting, Cultivating, and Protecting & 4.22 & 3.37 & 4.50 & 4.69 & 3.87 \\
\hline 741 & Veterinary Services for Livestock & 9.63 & 6.76 & 4.46 & 4.69 & 5.49 \\
\hline 2011 & Meat Packing Plants & 4.76 & 2.26 & 5.06 & 4.73 & 7.23 \\
\hline 2013 & Sausages and Other Prepared Meat Products & 4.76 & 2.26 & 4.78 & 4.71 & 6.62 \\
\hline 2015 & Poultry Slaughtering and Processing & 4.76 & 2.85 & 4.80 & 4.71 & 7.57 \\
\hline 2024 & Ice Cream and Frozen Desserts & 3.66 & 3.75 & 4.80 & 4.73 & 5.64 \\
\hline 2021 & Creamery Butter & 3.66 & 3.75 & 4.55 & 4.70 & 5.66 \\
\hline 2022 & Natural, Processed, and Imitation Cheese & 3.66 & 3.75 & 4.97 & 4.75 & 7.27 \\
\hline 2038 & Frozen Specialties, Not Elsewhere Classified & 4.94 & 3.28 & 4.68 & 4.72 & 7.79 \\
\hline 2092 & Prepared Fresh or Frozen Fish and Seafoods & 4.76 & 4.05 & 4.66 & 4.72 & 10.00 \\
\hline 2034 & Dried and Dehydrated Fruits, Vegetables, and Soup Mixes & 4.52 & 3.97 & 4.59 & 4.71 & 9.22 \\
\hline 2066 & Chocolate and Cocoa Products & 5.36 & 4.14 & 4.71 & 4.78 & 7.77 \\
\hline 2041 & Flour and Other Grain Mill Products & 3.76 & 4.57 & 4.78 & 4.71 & 5.22 \\
\hline 2043 & Cereal Breakfast Foods & 4.33 & 4.27 & 4.57 & 4.70 & 9.67 \\
\hline 2044 & Rice Milling & 3.76 & 4.57 & 4.55 & 4.70 & 5.19 \\
\hline 2045 & Prepared Flour Mixes and Doughs & 5.21 & 3.28 & 4.49 & 4.69 & 4.37 \\
\hline 2051 & Bread and Other Bakery Products, Except Cookies and Crackers & 5.21 & 3.28 & 5.12 & 4.74 & 5.18 \\
\hline 2053 & Frozen Bakery Products, Except Bread & 5.21 & 3.28 & 4.50 & 4.70 & 5.24 \\
\hline 2061 & Cane Sugar, Except Refining & 5.36 & 4.14 & 4.69 & 4.77 & 9.94 \\
\hline 2062 & Cane Sugar Refining & 5.36 & 4.14 & 5.48 & 5.06 & 9.15 \\
\hline 2063 & Beet Sugar & 5.36 & 4.14 & 4.48 & 4.70 & 8.82 \\
\hline 2068 & Salted and Roasted Nuts and Seeds & 4.76 & 4.05 & 4.94 & 4.80 & 9.54 \\
\hline 2074 & Cottonseed Oil Mills & 3.76 & 4.57 & 4.47 & 4.69 & 3.94 \\
\hline 2075 & Soybean Oil Mills & 3.76 & 4.57 & 4.49 & 4.70 & 6.97 \\
\hline 2087 & Flavoring Extracts and Flavoring Syrups, Not Elsewhere Classified & 4.76 & 4.05 & 4.77 & 4.74 & 7.67 \\
\hline 2097 & Manufactured Ice & 3.54 & 5.31 & 4.55 & 4.72 & 3.55 \\
\hline 2759 & Commercial Printing, Not Elsewhere Classified & 4.52 & 4.12 & 4.49 & 4.70 & 5.60 \\
\hline 2761 & Manifold Business Forms & 4.52 & 4.12 & 4.46 & 4.69 & 4.45 \\
\hline 7349 & Building Cleaning and Maintenance Services, Not Elsewhere & 6.55 & 2.57 & 4.46 & 4.69 & 3.45 \\
\hline 7381 & Detective, Guard, and Armored Car Services & 3.72 & 3.93 & 4.46 & 4.69 & 3.58 \\
\hline 7382 & Security Systems Services & 3.72 & 3.93 & 4.46 & 4.69 & 3.75 \\
\hline
\end{tabular}




\begin{tabular}{|c|c|c|c|c|c|c|}
\hline 8744 & Facilities Support Management Services & 6.02 & 5.77 & 4.46 & 4.69 & 3.31 \\
\hline 7359 & Equipment Rental and Leasing, Not Elsewhere Classified & 3.38 & 3.94 & 5.18 & 4.83 & 3.87 \\
\hline 7361 & Employment Agencies & 5.93 & 7.77 & 4.80 & 4.78 & 3.42 \\
\hline 7363 & Help Supply Services & 6.77 & 5.68 & 5.03 & 4.84 & 3.81 \\
\hline 7311 & Advertising Agencies & 6.45 & 8.66 & 5.59 & 5.00 & 3.76 \\
\hline 7335 & Commercial Photography & 5.65 & 6.95 & 4.46 & 4.69 & 3.52 \\
\hline 7336 & Commercial Art and Graphic Design & 7.12 & 8.79 & 4.50 & 4.71 & 3.78 \\
\hline 8732 & Commercial Economic, Sociological, and Educational Research & 6.18 & 8.86 & 4.46 & 4.69 & 4.34 \\
\hline 8711 & Engineering Services & 3.60 & 8.74 & 5.20 & 5.18 & 4.12 \\
\hline 8721 & Accounting, Auditing, and Bookkeeping Services & 7.68 & 8.36 & 5.23 & 4.74 & 4.59 \\
\hline 8742 & Management Consulting Services & 5.44 & 8.96 & 5.10 & 4.89 & 4.78 \\
\hline 6399 & Insurance Carriers, Not Elsewhere Classified & 7.37 & 7.41 & 4.62 & 4.74 & 4.59 \\
\hline 7323 & Credit Reporting Services & 7.84 & 4.81 & 4.46 & 4.69 & 3.68 \\
\hline 6411 & Insurance Agents, Brokers, and Service & 7.37 & 7.41 & 6.75 & 5.43 & 5.13 \\
\hline 6719 & Offices of Holding Companies, Not Elsewhere Classified & 6.31 & 7.93 & 10.00 & 6.47 & 6.72 \\
\hline 8111 & Legal Services & 6.98 & 8.91 & 5.50 & 5.03 & 3.56 \\
\hline 3211 & Flat Glass & 3.54 & 3.72 & 5.16 & 4.86 & 10.00 \\
\hline 3273 & Ready-Mixed Concrete & 2.06 & 3.23 & 5.82 & 5.56 & 3.75 \\
\hline 3296 & Mineral Wool & 2.76 & 3.95 & 4.53 & 4.70 & 5.15 \\
\hline 3316 & Cold-Rolled Steel Sheet, Strip, and Bars & 2.14 & 3.40 & 6.40 & 5.63 & 6.51 \\
\hline 3449 & Miscellaneous Structural Metal Work & 2.55 & 3.50 & 4.52 & 4.76 & 6.23 \\
\hline 2434 & Wood Kitchen Cabinets & 3.57 & 3.25 & 4.54 & 4.70 & 7.37 \\
\hline 2452 & Prefabricated Wood Buildings and Components & 2.80 & 2.89 & 4.50 & 4.70 & 7.89 \\
\hline 2521 & Wood Office Furniture & 3.57 & 3.25 & 4.52 & 4.70 & 8.73 \\
\hline 2531 & Public Building and Related Furniture & 3.86 & 4.04 & 4.51 & 4.70 & 7.39 \\
\hline 1611 & Highway and Street Construction, Except Elevated Highways & 1.90 & 2.99 & 5.45 & 4.78 & 4.45 \\
\hline 1623 & Water, Sewer, Pipeline, and Communications and Power Line Construction & 1.90 & 2.99 & 4.99 & 4.74 & 3.71 \\
\hline 1629 & Heavy Construction, Not Elsewhere Classified & 1.90 & 2.99 & 5.78 & 4.81 & 4.44 \\
\hline 3534 & Elevators and Moving Stairways & 1.90 & 2.99 & 4.56 & 4.72 & 8.03 \\
\hline 1799 & Special Trade Contractors, Not Elsewhere Classified & 1.97 & 2.98 & 4.48 & 4.70 & 3.85 \\
\hline 1711 & Plumbing, Heating and Air-Conditioning & 1.90 & 2.99 & 4.48 & 4.70 & 3.69 \\
\hline 1721 & Painting and Paper Hanging & 1.90 & 2.99 & 4.47 & 4.70 & 3.36 \\
\hline 1731 & Electrical Work & 1.90 & 2.99 & 4.48 & 4.70 & 4.01 \\
\hline 1742 & Plastering, Drywall, Acoustical, and Insulation Work & 1.90 & 2.99 & 4.46 & 4.69 & 3.42 \\
\hline 1751 & Carpentry Work & 1.90 & 2.99 & 4.47 & 4.70 & 3.66 \\
\hline 1761 & Roofing, Siding, and Sheet Metal Work & 1.90 & 2.99 & 4.47 & 4.69 & 3.49 \\
\hline 7819 & Services Allied to Motion Picture Production & 5.72 & 7.47 & 4.46 & 4.69 & 4.59 \\
\hline 7812 & Motion Picture and Video Tape Production & 4.63 & 6.73 & 4.79 & 4.74 & 4.40 \\
\hline 7922 & $\begin{array}{l}\text { Theatrical Producers (Except Motion Picture) and Miscellaneous Theatrical } \\
\text { Services }\end{array}$ & 5.63 & 6.70 & 4.84 & 4.85 & 3.55 \\
\hline 2711 & Newspapers: Publishing, or Publishing and Printing & 5.42 & 7.64 & 4.50 & 4.70 & 3.79 \\
\hline 2721 & Periodicals: Publishing, or Publishing and Printing & 5.99 & 8.97 & 4.48 & 4.70 & 4.50 \\
\hline 4832 & Radio Broadcasting Stations & 4.63 & 6.89 & 4.76 & 4.86 & 3.88 \\
\hline
\end{tabular}




\begin{tabular}{|c|c|c|c|c|c|c|}
\hline 4833 & Television Broadcasting Stations & 4.63 & 6.89 & 4.69 & 4.82 & 4.30 \\
\hline 7313 & Radio, Television, and Publishers' Advertising Representatives & 6.45 & 8.66 & 4.52 & 4.71 & 3.75 \\
\hline 8221 & Colleges, Universities, and Professional Schools & 6.86 & 8.41 & 5.21 & 5.26 & 3.52 \\
\hline 8299 & Schools and Educational Services, Not Elsewhere Classified & 7.83 & 7.62 & 4.51 & 4.73 & 3.32 \\
\hline 8222 & Junior Colleges and Technical Institutes & 6.86 & 8.41 & 4.48 & 4.71 & 3.32 \\
\hline 8249 & Vocational Schools, Not Elsewhere Classified & 6.88 & 7.68 & 4.48 & 4.70 & 3.29 \\
\hline 6324 & Hospital and Medical Service Plans & 7.00 & 7.72 & 4.85 & 4.82 & 3.35 \\
\hline 8071 & Medical Laboratories & 8.05 & 6.72 & 4.53 & 4.73 & 3.45 \\
\hline 8082 & Home Health Care Services & 10.00 & 4.67 & 4.47 & 4.69 & 3.26 \\
\hline 8099 & Health and Allied Services, Not Elsewhere Classified & 8.26 & 7.40 & 4.59 & 4.74 & 3.29 \\
\hline 8069 & Specialty Hospitals, Except Psychiatric & 8.94 & 7.98 & 4.52 & 4.69 & 4.15 \\
\hline 8062 & General Medical and Surgical Hospitals & 8.94 & 7.98 & 5.59 & 5.23 & 3.34 \\
\hline 8021 & Offices and Clinics of Dentists & 9.75 & 6.76 & 4.55 & 4.71 & 3.28 \\
\hline 8049 & Offices and Clinics of Health Practitioners, Not Elsewhere Classified & 9.43 & 9.24 & 4.51 & 4.70 & 3.33 \\
\hline 8093 & Specialty Outpatient Facilities, Not Elsewhere Classified & 9.20 & 8.02 & 4.56 & 4.75 & 3.24 \\
\hline 7011 & Hotels and Motels & 7.14 & 3.85 & 10.00 & 10.00 & 3.52 \\
\hline 7021 & Rooming and Boarding Houses & 6.68 & 4.33 & 5.12 & 5.40 & 3.26 \\
\hline 7041 & Organization Hotels and Lodging Houses, on Membership Basis & 7.10 & 3.88 & 5.28 & 5.57 & 3.37 \\
\hline 7999 & Amusement and Recreation Services, Not Elsewhere Classified & 6.13 & 5.37 & 6.11 & 5.36 & 3.44 \\
\hline 7032 & Sporting and Recreational Camps & 6.68 & 4.33 & 5.10 & 5.38 & 3.43 \\
\hline 7996 & Amusement Parks & 6.02 & 4.57 & 6.62 & 5.79 & 3.93 \\
\hline 8412 & Museums and Art Galleries & 6.49 & 6.32 & 4.61 & 4.69 & 3.58 \\
\hline 8422 & Arboreta and Botanical or Zoological Gardens & 6.49 & 6.32 & 4.61 & 4.69 & 3.88 \\
\hline 7514 & Passenger Car Rental & 4.05 & 5.00 & 4.77 & 4.75 & 3.58 \\
\hline 4724 & Travel Agencies & 7.52 & 6.52 & 4.72 & 5.05 & 5.48 \\
\hline 4489 & Water Transportation of Passengers, Not Elsewhere Classified & 4.14 & 5.13 & 4.86 & 4.72 & 4.20 \\
\hline 4729 & Arrangement of Passenger Transportation, Not Elsewhere Classified & 4.65 & 4.65 & 4.48 & 4.72 & 7.04 \\
\hline 4725 & Tour Operators & 7.52 & 6.52 & 4.52 & 4.78 & 3.79 \\
\hline 4522 & Air Transportation, Nonscheduled & 6.16 & 6.53 & 4.90 & 4.75 & 4.45 \\
\hline 4581 & Airports, Flying Fields, and Airport Terminal Services & 4.70 & 3.52 & 4.49 & 4.70 & 4.40 \\
\hline 3715 & Truck Trailers & 3.74 & 4.24 & 4.67 & 4.70 & 10.00 \\
\hline 4213 & Trucking, Except Local & 2.26 & 2.55 & 4.67 & 4.70 & 3.85 \\
\hline 4215 & Courier Services, Except by Air & 3.32 & 3.75 & 4.55 & 4.71 & 4.02 \\
\hline 4741 & Rental of Railroad Cars & 3.71 & 4.17 & 4.47 & 4.69 & 3.21 \\
\hline 4222 & Refrigerated Warehousing and Storage & 4.24 & 2.57 & 5.20 & 4.94 & 3.80 \\
\hline 4783 & Packing and Crating & 3.72 & 4.05 & 4.47 & 4.69 & 3.65 \\
\hline 4491 & Marine Cargo Handling & 3.72 & 4.05 & 4.47 & 4.70 & 6.00 \\
\hline 4499 & Water Transportation Services, Not Elsewhere Classified & 4.09 & 4.57 & 4.47 & 4.69 & 5.65 \\
\hline
\end{tabular}




\section{Annex 5: Methodology for Estimating Missing Inputs}

A crucial element for the development of any productive activity is a firm's capacity to access the intermediate inputs required in the production process, which are usually supplied by third parties, whether domestic or imported. The ability to access intermediate inputs in a given location is critical to determining the viability of the industry in it. In order for an intermediate input to be available in a particular location, it is not necessary that the industries that offer it exist in the same location; it is sufficient that the input be accessible through imports (to the extent that the input is tradable). In view of its relevance, the Growth Lab developed a methodology to measure a particular country's performance on this factor, based on information from U.S. Input-Output tables. As noted in the report, using data from the U.S. economy is useful not only because the country has accessible and reliable databases but because it also displays an advanced productive structure and a wide collection of industries, which can provide a good approximation to how individual industries in Jordan would interact with each other if and when they are fully developed.

The methodology first identifies which goods and services are intensively required by the industries of interest. To this end, an RCA for the employment of different inputs (RCAI) is calculated for every industry. This indicator is analogous to the one used to measure the intensity in which an industry is developed in the country. In the case of the RCAI, the share of the total demand for inputs of the specific industry that is given by a particular input, is divided by the average share of that input in all the industries in the economy. If the RCAI is equal to or greater than one, the input is demanded intensively by the industry in question, relative to the rest of the economy.

Next, to assess whether the inputs intensively required by the diversification opportunities identified are available in the country, a combination of two tests is applied. The first test evaluates if the input, an industry in itself, is present in the country. For this, the traditional RCA measure is used. If the industry shows an RCA equal to or greater than one, then the input that it offers is considered to be available. If this is not the case, the second test evaluates if other industries that intensively demand the same input are present in the country (using RCA). If a sufficiently large number (10 or more) of industries meet this criterion, then the input is also considered to be available. In short, the methodology presumes that an input is available in Jordan if it comes from an industry that is intensively present in Jordan or if a sufficiently large number of industries that intensively demand it are intensively present in Jordan.

The result of this exercise is a list of the intermediate inputs that are intensively demanded by each diversification opportunity, which can be classified either as available or missing. Performance on this factor is measured by the total number of inputs that are intensively required by the industry in question that are considered to be missing or not accessible in the country. 


\section{Annex 6: Methodology for Estimating Foreign Direct Investment}

Among the attractiveness factors that are considered in the prioritization exercise, a measure of Foreign Direct Investment (FDI) flows both at a worldwide and regional level is used. To assign an estimate of FDI flows to each SIC4 industry that was selected based on the complexity analysis, a two-part process is employed: (1) matching of the selected SIC4 industries to FDI categories, and (2) assignment of FDI flows based on employment, according to the Dun \& Bradstreet (D\&B) dataset.

The goal of the first step is to overcome the differences in classification codes between the fDi Markets dataset (NAICS 2007) and the D\&B dataset (SIC1987) that is used in the complexity analysis. For the industries that match with multiple FDI subsectors, one industry was chosen manually through careful study of the codes' definitions in both classifications. When the match at the SIC4 level became difficult, a match was made at a more aggregate level (for example, SIC2 level matched to an FDI sector, SIC3 level matched to an FDI subsector, etc.). This is considered a partial match. Partial matches are more common because the SIC4 level of disaggregation is generally higher than the typical FDI subsector level of disaggregation. For the partial matches, only a part of the matched FDI category (sector or subsector) is assigned based on weights calculated from D\&B. Weights are calculated based on the proportion of employment in the SIC4 industry to the employment in the SIC2 or SIC3 category that matched with the FDI category.

An example may help to illustrate this: The closest match to the SIC4 industry "Radio Broadcasting Stations" (SIC 4832) is the FDI subsector "Radio and TV Broadcasting" (NAICS 5151). However, the latter clearly includes a wider range of industries than the former. An assignment of all of the FDI in this subsector to SIC industry 4832 would likely be an overstatement. Therefore, the amount of FDI in "Radio and TV Broadcasting," is weighted by the proportion of employment in SIC 4832 to SIC 483 (namely, "Radio and Television Broadcasting Stations") to get a measure of the FDI spent only on radio broadcasting stations.

This implies an assumption that total employment in an industry is proportional to the total FDI in that industry. As an important caveat, this may not be true across industries that have different levels of capital intensity. However, this approximation leads to higher variability in the assignment of FDI to the SIC4 industries, which is important for the purposes of the analysis. For full matches, a weight of one is used to assign the appropriate FDI flows. 


\section{Annex 7: Industries Excluded from the Analysis after Identification of Export}

\section{Themes}

\begin{tabular}{|c|c|}
\hline Sic4 & Industry Description \\
\hline 851 & Forestry Services \\
\hline 912 & Finfish \\
\hline 921 & Fish Hatcheries and Preserves \\
\hline 1499 & Miscellaneous Nonmetallic Minerals, Except Fuels \\
\hline 2121 & Cigars \\
\hline 2675 & Die-Cut Paper and Paperboard and Cardboard \\
\hline 2789 & Bookbinding and Related Work \\
\hline 2796 & Platemaking and Related Services \\
\hline 3821 & Laboratory Apparatus and Furniture \\
\hline 4789 & Transportation Services, Not Elsewhere Classified \\
\hline 4813 & Telephone Communications, Except Radiotelephone \\
\hline 4899 & Communications Services, Not Elsewhere Classified \\
\hline 4939 & Combination Utilities, Not Elsewhere Classified \\
\hline 4941 & Water Supply \\
\hline 4953 & Refuse Systems \\
\hline 6726 & $\begin{array}{l}\text { Functions Related to Depository Banking, Not Elsewhere Classified } \\
\text { Unit Investment Trusts, Face-Amount Certificate Offices, and Closed-End } \\
\text { Management Investment Offices }\end{array}$ \\
\hline 6732 & Educational, Religious, and Charitable Trusts \\
\hline 7342 & Disinfecting and Pest Control Services \\
\hline 7383 & News Syndicates \\
\hline 7389 & Business Services, Not Elsewhere Classified \\
\hline 7537 & Automotive Transmission Repair Shops \\
\hline 7622 & Radio and Television Repair Shops \\
\hline 7699 & Repair Shops and Related Services, Not Elsewhere Classified \\
\hline 7941 & Professional Sports Clubs and Promoters \\
\hline 7948 & Racing, Including Track Operation \\
\hline 7997 & Membership Sports and Recreation Clubs \\
\hline
\end{tabular}

